\title{
Antitrust, Law \& Economics, and the Courts
}

\section{Citation}

Louis Kaplow, Antitrust, Law \& Economics, and the Courts, 50 Law \& Contemp. Probs. 181 (1987).

\section{Published Version}

doi:10.2307/1191460

\section{Permanent link}

http://nrs.harvard.edu/urn-3:HUL.InstRepos:12206470

\section{Terms of Use}

This article was downloaded from Harvard University's DASH repository, and is made available under the terms and conditions applicable to Other Posted Material, as set forth at http:// nrs.harvard.edu/urn-3:HUL.InstRepos:dash.current.terms-of-use\#LAA

\section{Share Your Story}

The Harvard community has made this article openly available.

Please share how this access benefits you. Submit a story.

Accessibility 


\title{
ANTITRUST, LAW \& ECONOMICS, AND THE COURTS
}

\author{
LOUIS KAPLOW*
}

\section{INTRODUCTION}

In the past decade, a new picture of the antitrust landscape has begun to emerge. The dominant emphasis of the ever more popular view concerns the ascendance of economics in antitrust decisionmaking and doctrine, particularly in Supreme Court adjudication, which is leading the way for the lower courts.' Moreover, it is not just economic analysis in the abstract that supposedly has come to the forefront but the strand of economic argument associated with the Chicago School. ${ }^{2}$ The new insight thought to be contained in this brand of economic analysis is allegedly responsible for the doctrinal shifts that generally have narrowed the scope of antitrust liability.

This perceived trend has become all the more salient with the appointment to the federal courts of appeals of the three leading academic proponents of this "new learning"-Richard Posner, Robert Bork, and Frank Easterbrook. ${ }^{3}$ It is not the case, however, that these appointments are seen as central to the movement in doctrine, which is thought to be most strongly

\footnotetext{
Copyright (C) 1988 by Law and Contemporary Problems

* Professor, Harvard Law School; Faculty Research Fellow, National Bureau of Economic Research. I have benefited from the comments of participants in the workshop at Boston University and at the conference and from the research assistance of Debra Appel and Michael Sturm.

1. This article will not directly address the similar perceived trend concerning the antitrust enforcement agencies-the Department of Justice and FTC-although much of the analysis presented here would be applicable. Eleanor Fox's discussion of former FTC Chairman Miller advances similar arguments concerning the role of economics and politics in deciding cases. See Fox, Chairman Miller, the Federal Trade Commission, Economics and Rashomon, Law \& Contemp. Probs.,
} Autumn 1987, at 36-40, 54-55.

2. See, e.g., Gerhart, The Supreme Court and Antitrust Analysis: The (Near) Triumph of the Chicago School, 1982 SUP. Ct. Rev. 319; Posner, The Chicago School of Antitrust Analysis, 127 U. PA. L. Rev. 925 (1979).

3. The most well-known and representative works include R. Bork, The ANTItrust Paradox (1978); R. Posner, Antitrust Law (1976); R. Posner \& F. Easterbrook, Antitrust (2d ed. 1981). Each has also written numerous articles on antitrust, some of which will be discussed later in this article.

For the most part, this article will not directly discuss the opinions of these and other recentlyappointed "law and economics" judges. As yet, all but Posner have not rendered a large number of antitrust decisions, and the group of cases as a whole has been sufficiently straightforward that it provides little basis for assessing the likelihood that these appointments will have a unique and profound affect on the future course of antitrust law. Instead, this article will focus on the Supreme Court-the locus of most of the important developments-and on the commentary, of which the writings of these judges constitute a significant segment. At least in the antitrust context, the implicit assumption of this session of the conference and much of the rest, which suggests the merits of focusing on the economic analysis of a handful of recently-appointed judges, is belied by conclusions presented here to the effect that observed changes are largely inexplicable in terms of the application 
indicated by the Supreme Court's General Dynamics ${ }^{4}$ and Sylvania ${ }^{5}$ decisions in the mid-1970's. Rather, additional lower court judges of high visibility who are favorable to the movement are predicted to have an important influence in consolidating the Chicago law and economics revolution in antitrust doctrine.

The story just described is rather puzzling. Although frequent reference is made to the contrast between contemporary Supreme Court antitrust jurisprudence and that of the more interventionist Warren Court, little note is made of the parallel shifts in the direction taken by the Supreme Court in such areas as criminal procedure, the first amendment, enforcement of the civil rights and voting acts, and numerous other areas of law. In light of these simultaneous developments by the same Court-and typically the same Justices-that are so well-known and frequently discussed, it is remarkable that commentary concerning doctrinal changes in antitrust is inclined to attribute the most recent swing in the antitrust pendulum to new economic insight rather than to larger political currents. ${ }^{6}$

Simply observing this broader context-which is virtually never to be seen even in the footnotes of most recent commentary concerning these developments in antitrust-is sufficient to cast serious doubt on the explanation based on the Supreme Court's recent learning of economics, Chicago style. ${ }^{7}$ Nor can the simple story be rescued through a broader claim suggesting that the law and economics perspective generally was responsible for all the recent shifts in Burger Court jurisprudence. Although law and economics has been applied to virtually all areas of law, ${ }^{8}$ and although some parallel developments do reflect more of an economic approach, ${ }^{9}$ it would be

of more sophisticated economic analysis and instead largely reflect more general shifts in politics and ideology.

4. United States v. General Dynamics Corp., 415 U.S. 486 (1974).

5. Continental T.V., Inc. v. GTE Sylvania, Inc., 433 U.S. 36 (1977).

6. Most examinations of the Burger Court's shift in antitrust doctrine make no mention of related shifts in other doctrines, analyzing the Court's views on antitrust as though the subject were sui generis. See, e.g., Markovits, The Burger Court, Antitrust, and Economic Analysis, in The BURGer CourT 180 (V. Blasi ed. 1983); Sullivan, The Economic Jurisprudence of The Burger Court's Antitrust Policy: The First Thirteen Years, 58 Notre Dame L. Rev. 1 (1982).

7. The interpretation presented in the text is not at all inconsistent with the Court's using Chicago School law and economics arguments in its opinions as part of the written rationalization. It is well known that countless reasons may be offered in opinions to support results reached (sometimes unconsciously, sometimes not) on other grounds. See, e.g., J. Frank, Law and the MODERn Mind 100-04 (1930). Moreover, one would expect a court to cite academic literature supporting a more general shift in position, even if the scholarship itself had little if any direct influence. It also is not the case that the Burger Court was generally anxious to adopt economic analysis as a general matter. (No substantial evidence yet exists with regard to the Rehnquist Court.) For example, the majority in Allen v. Wright, 468 U.S. 737 (1984), ignored Justice Stevens' application of simple supply and demand analysis in determining causation in a standing inquiry, see id. at 788-89 \& n.6, instead choosing to characterize the connection as "indirect" and "merely speculative," id. at 757-58. Numerous other instances could be offered, all suggesting that interpreting the Burger Court's jurisprudence on the assumption that it has accepted economics as a preferred mode of analysis is a far more problematic approach than one looking to easily identifiable patterns in its results. Finally, later discussion in this article will indicate that the actual use of Chicago law and economics in recent antitrust decisions is overstated.

8. See, e.g., R. Posner, Economic Analysis of Law (3d ed. 1986).

9. See, e.g., Mathews v. Eldridge, 424 U.S. 319, 334-35 (1976) (cost-benefit formulation for determining what process is due). More generally, Frank Easterbrook has claimed that Supreme 
extremely difficult to make the case that the broad changes in Supreme Court doctrine are primarily or even substantially explained by these phenomena. ${ }^{10}$

This article indicates how the common portrayal of developments in antitrust doctrine is mistaken and misleading. Part II questions whether there really has been a significant change in the use of economic analysis when addressing economic issues that arise in antitrust. Part III casts doubt on the implicit assumption that significant changes in the teachings of economic analysis can account for changes in antitrust doctrine and perspectives. Part IV considers the existence and meaning of a fundamental shift in the role of economic issues in deciding antitrust cases-that is, whether economics has officially been deemed the exclusive rather than merely an important objective of antitrust. Suggestions that the landscape has thus been radically altered are overstated, although there surely appears to have been some movement in that direction. Yet, when the arguments of the first parts are combined with an understanding of the history of the antitrust laws, it becomes clear that the shift in both doctrine and rationale witnessed in recent years is fundamentally a political, not an economic, phenomenon. As a result, the antitrust picture blends rather comfortably into the larger canvas portraying legal change in the federal courts.

Court Justices have generally become more sophisticated in economic reasoning. See Easterbrook, The Supreme Court, 1983 Term-Foreword: The Court and the Economic System, 98 HARv. L. Rev. 4 (1984) [hereinafter Easterbrook, Foreword]; Tribe, Constitutional Calculus: Equal Justice or Economic Efficiency, 98 HaRv. L. Rev. 592 (1985) (reply to Easterbrook); Easterbrook, Method, Result, and Authority: A Reply, 98 HaRv. L. Rev. 622 (1985) [hereinafter Easterbrook, Reply]. The first two of Easterbrook's economic criteria are most readily examined. He claims that courts should take an ex ante rather than an ex post perspective-that is, they should primarily consider the effect of their rules in governing future conduct rather than focusing on the equity it works in the case at hand-and that they should apply marginal analysis rather than considering merely averages. Easterbrook, Foreword, supra, at 10-14.

Both of these points (the first being more familiar) have a long history. For example, the first amendment chilling effects concept (often applied in discussing overbreadth and vagueness) exhibits a particularly strong emphasis on an ex ante perspective and the less restrictive alternatives concept is an explicit use of marginal analysis. Likewise, the exclusionary rule has only modest force as an ex post argument but has been strongly defended on ex ante grounds (and similarly for Miranda warnings and many other criminal procedure requirements). There is surely room for argumentargument that would be most difficult to resolve-concerning the frequency with which such "economic" approaches have been applied over the decades, but even if the trend has been toward increasing use of such common sense insights that are frequently associated with economics, it seems hard to believe that these shifts are primarily responsible for most of the significant movements in Supreme Court doctrine over the most recent decades. (Note that Easterbrook does not insist that his claimed rise in use of the principles he discusses explains the general changes in doctrine, see, e.g., Easterbrook, Foreword, supra, at 4-5; Easterbrook, Reply, supra, at 622-23 (indicating that he does not claim that "application of the three normative principles leads to a determinate outcome in all (or even most) cases"), although he does see his pattern strongly in antitrust cases, see Easterbrook, Foreword, supra, at 58-59.)

10. The discussion of stated rationale for Supreme Court antitrust decisions in note 7 is applicable to references to economic reasoning in other contexts as well. 


\section{Has There Been a Significant Change in the Degree to which Economic ANalysis is used to Address Economic Issues?}

Statements that the new law and economics has come to dominate the Supreme Court's antitrust decisionmaking typically encompass some combination of three subsidiary claims: Economic analysis is used more frequently in addressing economic issues; economic analysis has come to yield different answers to economic questions; and economic questions have come to be more important in deciding antitrust cases. These three claims are discussed, respectively, in parts II-IV of this article. The first claim concerning the frequency with which economics is used in addressing concededly economic issues is by far the easiest to assess and yields the clearest answer. If one focuses on the last five decades-a span that includes virtually all of the cases, many by the Warren Court, most despised by Chicago law and economics-it seems rather clear that economic analysis always has played an important and central role in antitrust decisions. "I

The proposition that economics has long been accepted in antitrust, although contrary to much of current commentary, is really quite familiar. ${ }^{12}$ After all, the most prominent works in the 1950's took a decidedly economic approach, ${ }^{13}$ even if one omits the work of the Chicago School. ${ }^{14}$ It has been contemplated for decades, if not from the beginning, that economics would play an important role in analyzing antitrust issues. In fact, the law and economics movement of the past few decades is often thought of as involving the application of economics to all aspects of law except antitrust, regulation, and a few other fields-those in which the use of economics has long been taken for granted. ${ }^{15}$

The most notable antitrust opinions over this time period rather uniformly display the application of economic analysis, whatever one thinks of the quality or content of the analysis in particular opinions. Consider first the earlier decades. In his recent analysis, Frederick Rowe argues that the strong connection between economics and antitrust doctrine was established in the

11. The content of that analysis is the subject of part III. A similar claim could also be made for much of the first half-century of antitrust jurisprudence, although it is more difficult to analyze given that economic analysis of industry was not nearly as developed at the time. Since most current commentary focuses on the comparison of the last decade or two with the immediately preceding decades, this article will largely be limited in a similar manner.

12. See, e.g., Hovenkamp, Antitrust Policy After Chicago, 84 Мich. L. Rev. 213, 217-20 (1985).

13. See, e.g., J. Dirlam \& A. Kahn, Fair Competition: The Law and Economics of Antitrust Policy (1954); C. Kaysen \& D. Turner, Antitrust Policy (1959).

14. See, e.g., Bowman, Tying Arrangements and the Leverage Problem, 67 Yale L.J. 19 (1957); Director \& Levi, Law and the Future: Trade Regulation, 51 Nw. U.L. REv. 281 (1956).

15. For example, a large number of the recent texts on law and economics do not even have index entries for antitrust, much less any significant treatment. See, e.g., C. Goetz, Law and Economics (1984); H. Manne, The Economics of Legal Relationships (1975); A.M. Polinsky, AN InTroduction to LAW and Economics (1983). The primary exception is Richard Posner's Economic Analysis of Law, supra note 8, which devotes two of twenty-eight chapters to antitrust, a hardly surprising fact given that one of Posner's primary fields has long been antitrust. 
1940's. ${ }^{16}$ That the heavy use of economics in leading antitrust decisions dates back at least this far is amply supported by a consideration of the most salient cases of the period. Learned Hand's opinion in Alcoa ${ }^{17}$-one frequently and heavily criticized in the new law and economics of antitrust ${ }^{18}$-is well-known for its extensive discussion of market definition and its relation to market power, one that greatly surpassed most of what had come before (and much of what has come after) in economic sophistication. ${ }^{19}$ United Shoe, ${ }^{20}$ another of the leading monopolization opinions of the earlier era that has been heavily criticized by the new law and economics of antitrust, ${ }^{21}$ is particularly known for its heavy use of economic analysis. ${ }^{22}$ The Supreme Court's Cellophane opinion, ${ }^{23}$ which contains one of the most prominent and extensive discussions of market definition of the period, relies heavily on economic concepts, such as the cross-elasticity of demand. ${ }^{24}$ In the merger area, Brown Shoe ${ }^{25}$ is the most criticized opinion. ${ }^{26}$ Yet it is also known for reading the rather ambiguous language of the 1950 amendment to the Clayton Act- "in any line of commerce in any section of the country"27-as referring to product and geographic markets in the sense economists mean by those terms. ${ }^{28}$ Although the examples could be multiplied, ${ }^{29}$ it suffices for the purposes of this argument to have established the prevalence of economic analysis in a number of the most prominent opinions of the era, and in

16. Rowe, The Decline of Antitrust and the Delusions of Models: The Faustian Pact of Law and Economics, 72 GEo. L.J. 1511, 1520-22 (1984); see also supra note 11 (discussing whether it might have begun even earlier).

17. United States v. Aluminum Co. of Am., 148 F.2d 416 (2d Cir. 1945).

18. See, e.g., R. Bork, supra note 3, at 52-52, 165-70 (“Alcoa opinion . . stands revealed as a thoroughly perverse judicial tour de force"'); R. POSNER, supra note 3, at 206-07, 214-15.

19. See 148 F.2d at 424-27. The claim here is not that Hand's analysis is beyond criticism based on the economic analysis of the time or that developed since, but rather that his opinion reflects a serious and substantial attempt to apply economics to antitrust.

20. United States v. United Shoe Mach. Corp., 110 F. Supp. 295 (D. Mass. 1953), aff'd per curiam, 347 U.S. 521 (1954).

21. See, e.g., R. Bork, supra note 3, at 138-42, 170-73, 181-82; R. Posner, supra note 3, at 202-06, 215-16.

22. Judge Wyzanski employed economist Carl Kaysen to assist him in the case. See C. Kaysen, United States v. United Shoe Machinery Corp. (1956).

23. United States v. E.I. Du Pont De Nemours \& Co., 351 U.S. 377 (1956).

24. This opinion, which favored the defendant, has long been criticized for misanalyzing the question. Many commentators have found more persuasive the arguments in the dissent, which also relied heavily on economic analysis and cited the most relevant economic literature. See 351 U.S. at 414-25 (citing Stocking \& Meuller, The Cellophane Case, 45 AM. Econ. Rev. 29 (1955)).

25. Brown Shoe Co. v. United States, 370 U.S. 294 (1962).

26. See, e.g., R. BoRk, supra note 3, at 200-08, 210-16; R. PosNer, supra note 3, at 100-05, $129-30$.

27. 15 U.S.C. $\$ 18$ (1982 \& Supp. III 1985).

28. See 370 U.S. at 324, 335; see also United States v. Philadephia Nat'l Bank, 374 U.S. $321,362-$ 63 (1963) (indicating that presumptive approach is "fully consonant with economic theory" and relying heavily on economists and other commentators strongly influenced by economics). Once again, the claim in the text only concerns whether economic analysis is employed in a substantial manner, not the quality of the analysis or the conclusions reached.

29. For example, the much criticized case of Standard Oil Co. v. United States (Standard Stations), 337 U.S. 293 (1949), see, e.g., R. BORK, supra note 3, at 299-301; R. PosneR, supra note 3, at 201-02, explicitly used economic grounds to justify a more lenient treatment of requirements contracts than tying arrangements, despite identical statutory language. See 337 U.S. at 307-08. 
particular those now most heavily criticized by the new law and economics of antitrust.

Given this history, it would be rather difficult to imagine that antitrust decisions of the most recent fifteen years could reflect a substantially greater use of economics in addressing economic questions than was employed in these earlier times. In fact, the more recent cases best known for signaling the new direction of the Supreme Court exhibit a similar level of reliance on economic analysis. Although widely heralded as indicating a new direction for the Supreme Court in the merger area, ${ }^{30}$ analysis of the decision in General Dynamics ${ }^{31}$ reveals surprisingly little change of any kind. That opinion is most known for looking beyond simple market share statistics. The Court's primary observation was that past market share was a poor predictor of the future in this unique market. Companies with significant past sales of coal, such as one of the merger partners in the case, might be of little competitive significance in the future if they were almost out of reserves.

This point hardly reflects the application of new or particularly sophisticated economic analysis. ${ }^{32}$ Moreover, the Court explicitly quoted Brown Shoe-that earlier and allegedly anti-economic analysis opinion-in support of its claim that it was appropriate to look beyond simple market share statistics. ${ }^{33}$ In addition, the reasoning behind this departure from market share statistics is rather limited. ${ }^{\mathbf{3 4}}$

Nor did the dissent, consisting of the Warren Court holdovers, ${ }^{35}$ disagree in principle with the majority's willingness to move beyond market share statistics based on past sales to consider reserves. Instead it argued that reserves should have been considered at the time of the merger, when the now-depleted company did in fact possess substantial reserves. Furthermore, the dissent suggested that the company's deep-mine reserves, although not currently being mined, should be included because the company had previous deep-mining experience. ${ }^{36}$ Whatever one thinks of the merits of this dispute, the dissent's position is hardly one that can be characterized as opposition in principle to the application of economic analysis. General Dynamics therefore involved no revolution in the use of economics in antitrust decisionmaking. ${ }^{37}$

30. See, e.g., Baxter, Reflections upon Professor Williamson's Comments, 27 ST. Louls U.L.J. 316, 317. 18 (1983).

31. United States v. General Dynamics Corp., 415 U.S. 486 (1974).

32. Not surprisingly, the Court did not find it necessary to cite any commentary by economists or others influenced by economics to motivate or support its analysis. The only such citations in the majority opinion involve a passing reference to alternative rationales for the failing-company defense. See id. at 507 n.15.

33. Id. at 498.

34. See, e.g., id. at 500 .

35. The dissent was written by Justice Douglas, joined by Justices Brennan, White, and Marshall. The only other remaining Justice from the Warren Court was Justice Stewart, the author of the majority opinion, who had been a regular dissenter in Warren Court merger cases. See, e.g., United States v. Von's Grocery Co., 384 U.S. 270, 301 (1966) ("The sole consistency that I can find is that under $\$ 7$, the Government always wins.").

36. See 415 U.S. at 524-26.

37. Robert Bork seems to agree with this characterization, and finds it unfortunate. See $\mathbf{R}$. Bork, supra note 3, at 218. 
The most-cited decision in discussions of the rise of economics in antitrust is Sylvania. ${ }^{38}$ In at least one important sense, this case did involve a substantial departure from the past: It reversed part of the Court's decision in Schwinn. ${ }^{39}$ Much of the Court's criticism of Schwinn was directed to its formalism. This criticism had been emphasized previously by numerous commentators, who did not base their arguments particularly on economic analysis. ${ }^{40}$ Of course, an important part of the Court's basis for permitting territorial restrictions was economic arguments that had come to receive wider attention. ${ }^{41}$ Such reliance, however, is hardly a characteristic unique to this opinion or to antitrust decisions generally. ${ }^{42}$ Furthermore, the Court's acceptance of the economic arguments was limited. ${ }^{43}$

Some of the other more prominent antitrust opinions of the past decade reflect the use of economic analysis while others show less evidence. ${ }^{44}$ In any event, it is clearly not the case that there has occurred a fundamental change in the view of courts concerning whether economic analysis provides a useful and important source of wisdom concerning antitrust law. Economics was well received by courts and commentators alike long before the recent emergence of the new law and economics of antitrust. If changes are to be identified, therefore, it must be either in the content of the economic analysis, which is explored in the next part of this article, or elsewhere.

38. Continental T.V., Inc. v. GTE Sylvania, Inc., 433 U.S. 36 (1977).

39. United States v. Arnold, Schwinn \& Co., 388 U.S. 365 (1967). Schwinn itself had reversed the earlier Warren Court decision adopting a rule of reason approach. White Motor Co. v. United States, 372 U.S. 253 (1963). None of the recent commentators have suggested, however, that White Motor demonstrates that the Warren Court had originally adopted an economic approach, only later to be rejected in Schwinn.

40. See 433 U.S. at $47-54$ \& n.13.

41. See id. at 54-58.

42. William Baxter argues that "the insight that not all forms of rivalry are beneficial" is clearly one that "the Court had never previously had." Baxter, supra note 30 , at 318 . This interpretation is rather surprising. After all, the rule of reason adopted in Sylvania was that from Chicago Board of Trade, see 433 U.S. at $49 \mathrm{n} .15$, a case that six decades earlier upheld (rightly or wrongly) restraints on rivalry as beneficial to competition. And the Court's earlier application of the rule of reason in this context in White Motor Co., 372 U.S. at 261-62 (quoting the same passage from Chicago Board), was premised on this possibility. One could also note the cases upholding restrictive practices by patentees, and many others. Interestingly, in an earlier statement defending the proposition that "consumer welfare" should be the sole goal of antitrust, Baxter explicitly argued that the Supreme Court in the 1890 's recognized that there existed "categories of agreements which did eliminate rivalry but nevertheless were permissible under the [Sherman] Act." Baxter, Placing the Burger Court in Perspective, 47 Antitrust L.J. 803, 804 (1978) (footnote omitted).

43. See, e.g., Markovits, supra note 6, at 191 (noting three respects in which the economic argument was not followed, but seeing the opinion as "a significant step in the right direction").

44. Frank Easterbrook purports to offer a long list of recent Supreme Court decisions that have been strongly influenced by the Chicago School efficiency approach. See Easterbrook, Workable Antitrust Policy, 84 Mich. L. Rev. 1696, $1698 \mathrm{n} .7$ (1986). Yet virtually none of the cases he cites contain any significant economic analysis or reflect any significant change in approach. Many cited portions explicitly rely on cases and principles long criticized by the Chicago School. And a few-in the portions he cites-explicitly refuse to take approaches he advocates, in one case (NCAA) quite directly, in that both the method and result he personally presented to the Court were rejected. 


\section{III}

\section{Has There Been a Significant Change in What Economic analysis Says about the Economic Issues in Antitrust Cases?}

The question whether there has been a substantial increase in the use of economics to analyze economic questions could be answered simply and in the negative. The question addressed in this part of the article, concerning the content of the economic analysis, is more complex. Section A describes how there have been a number of changes in the methodology and content of the relevant economic analysis over the past four decades. These changes, however, do not correspond to those frequently discussed by the Chicago School, and often run in precisely the opposite direction. Moreover, the current content of economic analysis hardly provides the unquestionable support that is often claimed for many of the Chicago School positions. Section B demonstrates the lack of any direct, strong connection between economic theory per se and the positions generally associated with the economic approach. This section explores both the methods used to examine markets and restrictive practices and those used to formulate legal rules (for example, the preference for the rule of reason). Lest the argument be misunderstood, the analysis presented here is not intended to be a thorough critique of Chicago School economics; many of its teachings are useful, and it is beyond the scope of this brief investigation to address thoroughly those that are not. ${ }^{45}$

\section{A. Changes in Economists' Analyses}

At one level, the claim that there has been a significant change in antitrust scholars' economic analyses of restrictive practices is undeniable. This shift can readily be seen in the leverage context, which involves the alleged extension of monopoly power from one market to another. Previous simplistic views concerning the possibility of leverage ${ }^{46}$ have been strongly critiqued by the Chicago School, often with little effective reply. ${ }^{47}$ It seems fair to say that, in its simplest form, the original leverage analysis has largely

45. For discussion and critique of a number of the Chicago School positions, see Hovenkamp, supra note 12, at 260-83; Kaplow, The Accuracy of Traditional Market Power Analysis and A Direct Adjustment Alternative; 95 HaRv. L. REv. 1817 (1982) [hereinafter Kaplow, Market Power]; Kaplow, Extension of Monopoly Power Through Leverage, 85 Colum. L. Rev. 515 (1985) [hereinafter Kaplow, Leverage]; Kaplow, The Patent-Antitrust Intersection: A Reappraisal, 97 HARv. L. REv. 1813 (1984); Scherer, The Posnerian Harvest: Separating Wheat from Chaff (Book Review), 86 YALE L.J. 974 (1977); Williamson, Antitrust Enforcement: Where It's Been, Where It's Going, 27 ST. Louis U.L.J. 289 (1983). It should be noted, however, that the cited critiques, although disagreeing with various aspects of Chicago School arguments, often are equally critical of many of the positions taken by those targeted by the Chicago School's attacks.

46. See, e.g., Kaplow, Leverage, supra note 45, at 516-17 (discussing and documenting the prevalence of the traditional view on leverage).

47. See, e.g., id. at 517-20 (reviewing the critique). 
vanished. Although the Chicago School position has been the subject of much criticism, the debate has hardly been resolved. ${ }^{48}$

More generally, despite the new law and economics criticism of many traditional views, it is not the case that the Chicago School of antitrust simply reflects application of the best and most current economic wisdom to the economic questions posed by antitrust law. Quite the contrary, the "price theory" widely hailed by the Chicago School as its heart and soul, ${ }^{49}$ although a useful starting point, is in fact the earliest and simplest form of economic analysis of industry. ${ }^{50}$ Much of the Chicago School commentary fails to appreciate that divergent work by economists was a response to the shortcomings of the simple price theory that Chicagoans hawk in competition with these other economic approaches. ${ }^{51}$

One dimension of the change in economic analysis concerns the work, which began in the 1930's and reached its peak in the 1950's, that involved the intensive study of particular industries ("case studies") for the purpose of gaining additional insight into their operation. ${ }^{52}$ Richard Posner has noted the difference between these two approaches and has criticized the case study method for being atheoretical. ${ }^{53}$ Yet case studies were not in line with existing theory precisely because it was suspected, and then discovered, that existing theory was itself not in line with reality. Because the general view of the Chicago School of economics, best exemplified in Milton Friedman's famous methodological article on the subject, is that theory is to be judged by its predictive power, ${ }^{54}$ one would think that the less rigorous ad hoc theories of those involved in performing case studies would be applauded because of the better match with reality. Such has not been the case. More importantly, this criticism of case studies misses the mark. Part of the goal of case studies has always been to learn from them in order to generate better theory. The complexity and variety of industry has often frustrated those hopes, but that is hardly a ground for criticizing the effort or for casting aside the valuable lessons gleaned from such endeavors.

Another important defect exists in the Chicago School's attempts to cling to simple price theory as offering the best insights for the new law and

48. See, e.g., id. at 520-26 (criticizing Chicago School economics arguments concerning leverage and citing criticism offered by many others).

49. See, e.g., R. Bork, supra note 3, at 116-33; Posner, supra note 2, at 928-29.

50. See, e.g., Rowe, supra note 16, at 1547. Robert Bork's view on this point appears to be much the same, see Bork, in Judicial Precedent and the New Economics, in Changing Antrtrust Standards 5, 5 6 (Conf. Bd. Research Bull. No. 144, 1983), although he later refers to the economic approach he advocates as "really an intellectual revolution in the academic world," id. at 11 . But see Breyer, in id. at 6, 11 (denying revolution; noting that such arguments on resale price maintenance have been around for twenty years); Fox, supra note 1, at 43 (describing change in FTC decisionmaking in Reagan Administration: "Economic arguments compatible with less government (while known for many years) began to command respect.").

51. See, e.g., Schmalensee, The New Industrial Organization and the Economic Analysis of Modern Markets, in Advances in Economic Theory 253, 253-55 (1982).

52. See, e.g., id.

53. See Posner, supra note 2, at 931.

54. See Friedman, The Methodology of Positive Economics, in M. Friedman, Essays in Positive Economics 3 (1953). 
economics of antitrust. Theoretical advances in microeconomics during the 1970's and 1980's have greatly surpassed the simple price theory formulated in the 1890's to provide an understanding of industrial practices. ${ }^{55}$ Much of this work, to be discussed in greater detail in section B, emphasizes the need for dynamic rather than static analysis, as well as the need to factor in the freerider problem when assessing strategic behavior. These recent advances also recognize the necessity of considering the implications of a variety of market imperfections that, while known for some time, have only recently been analyzed in sufficient depth to permit a greater understanding of their implications.

There have indeed been substantial changes in the methodology employed by economists studying industrial organization in the past decades, and the new learning of economists has substantial bearing on the appropriate content of antitrust doctrine. Some of this understanding favors the results advocated by the Chicago School, some is in opposition, and much is too tentative to permit confident conclusions at present. It is clearly not the case, however, that the methods and conclusions of the "new economics of antitrust," as embodied in the writings of the Chicago School, simply reflect what is new in economic analysis that has a bearing on antitrust.

Against this background, it is interesting to examine briefly Richard Posner's 1979 proclamation that the competing schools of antitrust analysis had largely converged-essentially establishing a near consensus on a moderate Chicago School stance:

I shall argue in this paper that although there was a time when the "Chicago" school stood for a distinctive approach to antitrust policy, especially in regard to economic questions, and when other schools, particularly a "Harvard" school, could be discerned and contrasted with it, the distinctions between these schools have greatly

55. See, e.g., Nelson, Comments on a Paper by Posner, 127 U. PA. L. Rev. 949, 949, 952 (1979); Schmalensee, supra note 51, at 255-57. In a footnote to his article that is followed by Nelson's comments, Posner sharply criticizes Nelson's argument in a rather surprising manner. See Posner, supra note 2, at $948 \mathrm{n} .69$. First, Nelson is castigated for not being a careful reader of the relevant economics literature. The claim is a bit surprising given that Nelson is a prominent economist and has himself written in the field. Similarly, Mike Scherer, one of the leading industrial organization economists, in reviewing Posner's book on antitrust, has noted Posner's failure to cite any of the relevant economics literature that cuts against many of his positions. See Scherer, supra note 45, at $976 \mathrm{n} .12$ (connection between market structure and innovation), 986-88 (efficiency motivations for mergers), 990 (scale economies in merger context), $991 \mathrm{n} .91$ (dynamic theory).

Posner then defends himself on the claim that the Chicago School ignores uncertainty, information, and search costs by noting that two Chicago economists played important formative roles in economic developments on these fronts. Although Posner's point is accurate, Nelson's criticism presumably was not that no one on premises at the University of Chicago ever considered such issues but rather that the analysis of Chicago School antitrust analysts has systematically ignored or underplayed such issues. On that point, there is much truth in Nelson's claim. See, e.g., Kaplow, Leverage, supra note 45, at 527-39; Williamson, supra note 45, at 298-312.

Finally, Posner emphasizes that Nelson does not state that the new literature supports different policy conclusions than those suggested by the Chicago School. On this ground, it is accurate to say that Nelson's four-page comment does not articulate and defend an alternative antitrust program. Moreover, much of the more recent literature, like much academic literature, is theoretical and not explicitly geared to particular proposals and doctrines. It is rather obvious, however, that much of the recent work of economists casts doubt on the Chicago School's conclusions, as many of the sources cited in this article attest. 
diminished. This has occurred largely as a result of the maturing of economics as a social science, and, as a corollary thereto, the waning of the sort of industrial organization that provided the intellectual foundations of the Harvard school. ${ }^{56}$

Moreover, any differences that remained he deemed "technical rather than ideological." 57 This general claim, which he explains as resulting from the abandonment of economic methodologies that diverged from price theory, is difficult to reconcile with both the past and current work by economists in the field. Posner does not, however, support his claim by referring to the work of industrial organization economists. Rather, he notes that, contrary to the state of affairs in the 1950's, the positions advanced in antitrust commentary by the leading scholars addressing a legal audience today are often very close to Chicago school positions. ${ }^{58}$ In addition, he does not cite a broad crosssection of current literature, virtually ignoring those who disagree with him. ${ }^{59}$

Much more recently, however, Posner appears to have adopted a far different outlook. His new description portrays "three warring camps," one explicitly divided from the others on social and political grounds-which would appear to retract the claim of no ideological differences-and the other two divided into competing economic camps-“"a 'Harvard School,' prone to find monopolistic practices, and a 'Chicago School,' which believes the same practices to be for the most part procompetitive." 60 Moreover, he states the belief that these differences reflect "deep and at the moment unbridgeable divisions in ethical, political, and economic thought." 61 These statements fairly describe the range of differences in antitrust today, including differences in how economic analysis is applied and what conclusions are thereby reached. The following section sketches some of the primary differences in economic approaches and how they relate to the antitrust doctrines advocated by different groups.

\section{B. Changes in Views of Antitrust Reflected in the New Law and Economics}

The Chicago School of antitrust has advanced the position that belief in rigorous economic analysis is associated with their particular views toward

56. Posner, supra note 2 , at 925 .

57. Id. at 948 .

58. A large portion of all the references contrast the positions in the Kaysen and Turner book from 1959, see C. Kaysen \& D. Turner, supra note 13, to those in the then-recently published volumes of Areeda and Turner's treatise, P. Areeda \& D. Turner, Antitrust Law (1978). Although one could argue about the degree to which the Areeda and Turner treatise agrees with Chicago School positions, that question is not central to the issue explored in text.

59. For example, the then-recent treatise by Sullivan is not cited. See L. Sullivan, Handoor of THE LAW OF ANTITRUST (1977). In addition, one would have thought that an author whose recent book, see $\mathbf{R}$. PoSNER, supra note 3 , had received a review by a prominent figure who disagreed strongly with a large portion of his major claims, see Scherer, supra note 45 , would be most reluctant to claim that the school with which he was associated had achieved consensus, even if he had strong justifications for disagreeing with such a review.

60. R. Posner, The Federal Courts $151-52$ (1985). He cites his article on the Chicago School for a description of the two camps, id. at $152 \mathrm{n} .34$, but makes no mention of the claim contained in that article to the effect that the separation between the camps had largely vanished.

61. Id. at 152 . 
antitrust. They offer opinions concerning the general operation of markets and the effects of particular restrictive practices. In addition, the new law and economics of antitrust is associated with certain preferences concerning procedural rules and presumptions, most notably the general preference for the rule of reason. The following two subsections consider whether the advocated positions on antitrust doctrine can best be understood simply as following from the application of economic analysis or instead as deriving from particular inclinations of those associated with the Chicago School.

1. Analysis of Markets and Practices. The Chicago School of antitrust generally believes that markets are largely self-correcting. Restrictive practices thus can be presumed to produce efficiencies rather than anticompetitive effects. ${ }^{62}$ Frank Easterbrook has claimed that " $[t]$ he fundamental premise of antitrust is the ability of competitive markets to drive firms toward efficient operation. The entire corpus of antitrust doctrine is based on the belief that markets do better than judges or regulators in rewarding practices that create economic benefit and penalizing others." 63 But if this were the fundamental premise, there would be no antitrust law. Antitrust law is necessarily based on the contrary assumption that courts at times can punish detrimental practices better than markets will. As a result, the tendency of the Chicago School to assume perfect markets ${ }^{64}$ when this may not be the case suggests that their economic analysis-even though rigorous and accurate in itself-is not always that most appropriate to the task. ${ }^{65}$ One of the most widely-noted shortcomings of Chicago School antitrust analysis is that it uses static models even when examining effects that are intrinsically dynamic - as in the case of all exclusionary practices that are alleged to affect market power over time. ${ }^{66}$

Problems with the Chicago School analysis can be illustrated by its heavy reliance on the survivorship concept-the idea that only efficient practices will survive in competitive markets. ${ }^{67}$ Although it is not possible to offer a complete discussion here, a few general criticisms should suffice to indicate the shortcomings of the approach. First, and most fundamentally, because it assumes that only efficient practices would survive, the approach largely begs

62. See, e.g., Easterbrook, The Limits of Antitrust, 63 TEX. L. REv. 1 (1984); sources cited supra note 3; supra at 190-91 (quoting Posner).

63. Easterbrook, supra note 62, at 24 (emphasis in original), discussed in Kaplow, Leverage, supra note 45 , at $556 \mathrm{n} .149$.

64. The point is not that literally perfect markets are assumed, but rather that substantial imperfections are often overlooked or given little weight.

65. See, e.g., Kaplow, Leverage, supra note 45, at 536-39; Williamson, supra note 45, at 298-312.

66. See, e.g., Hovenkamp, supra note 12, at 264-74; Kaplow, supra note 45, at 523-25, 527-31; Markovits, The Limits to Simplifying Antitrust: A Reply to Professor Easterbroook, 63 TEx. L. REv. 41, 83 (1984); Williamson, supra note 45, at 301, 304-06, 309, 311 ; Williamson, Book Review, 46 U. CHI. L. REv. 526, 528 (1979) (criticizing Bork).

67. The most explicit and thorough elaboration of this view in recent antitrust literature is Easterbrook, supra note 62. For a general discussion of the natural selection model outside the context of the survivorship of anticompetitive practices, see F.M. Scherer, Industrial Market Structure and Economic Performance 38-40 (2d ed. 1980); R. Hansen \& W. Samuelson, The Evolution of Economic Games (Feb. 1986) (unpublished manuscript). 
the question for antitrust purposes. ${ }^{68}$ This problem relates rather directly to the previously noted tendency of the Chicago School to assume perfect markets. Simply, one must ask why truly anticompetitive practices never can survive. Strategic considerations combined with well-recognized market imperfections make this query important. ${ }^{69}$

Second, the Chicago School's use of the survivorship concept often ignores or gives little weight to the question of how long the evolutionary process takes. ${ }^{70}$ If one had sufficient faith in self-correcting tendencies of the market, even a ban on cartels would be unnecessary, although most Chicago School analysts have stopped short of such a position. ${ }^{71}$ Similar reasoning also implies that market forces would tend to eliminate various forms of discrimination rather quickly in many contexts. A substantial history, however, as well as some current events, demonstrate that long time periods may be necessary for the process to work. ${ }^{72}$ That the problem may be largely one of substantial delay rather than a permanent lack of competition hardly renders antitrust unimportant. ${ }^{73}$

A third problem involves the precision of the selection process as industry evolves. When there are many practices and outsiders have difficulty determining which are efficient, as the Chicago School would argue is often the case, the process of imitation in the market will not function as quickly or

68. See Rowe, supra note 16, at 1549-50 ("Since nothing succeeds like success, that truism yields neither operational criteria nor predictive norms, for its circularities bless what prevails in the end."). Robert Bork surprisingly takes a rather similar position in explaining the merits of the price theory approach: "Microeconomic theory rests upon a few empirical premises. . . Once a few such basic premises are accepted, the rest follows like a proof in geometry. The system is entirely circular, which is its strength because circular logic is not rebuttable." Bork, supra note 50, at 10 . He is willing to make this statement presumably because he has utmost confidence in the premises of price theory, but it is precisely such premises that have been challenged for decades by economists moving beyond simple price theory. See supra section III-A.

69. See sources cited supra note 66 .

70. Final judgments in antitrust cases can also take a very long time, which must be taken into account in considering this issue. Despite this consideration, however, antitrust plays a significant role to the extent a large portion of restrictive practices are deterred. In addition, in many areas action will be rather quick, as in the case of mergers where prior approval is necessary. Finally, considerations of timing are obviously relevant in fashioning procedural rules and presumptions as well as in determining the scope of prohibited practices since the former regulations substantially affect the time it takes to reach final judgment in fully contested cases.

71. The OPEC cartel offers a notable example outside the jurisdiction of United States antitrust law. Although the cartel has often experienced difficulties and may finally be approaching its demise, it is worth recalling that over a decade ago many strong believers in the market predicted that it could never stay together long enough to have any significant effect. See, e.g., Friedman, The Economy and the 1976 Election, NewsweEk, Feb. 17, 1975, at 80 ("[T]he OPEC oil cartel will break down. . . The only question is how long it will take. . . [T]he chances are good that . . the cartel will begin to disintegrate by 1976 and crude-oil prices will start to tumble.").

72. It also may be questioned whether it might have taken far longer were it not for antidiscrimination law. Many will dispute how significant discrimination ever was in the past or how much continues to the present. For purposes of this article it suffices to note that there were numerous instances of clear and significant discrimination that lasted for decades at a minimum.

73. In discussing entry barriers, Richard Posner notes the example of U.S. Steel, where the delay spanned many decades. See R. Posner, supra note 3, at 197-98, discussed in Kaplow, Leverage, supra note $\mathbf{4 5}$, at 538 . 
as effectively as it otherwise would. ${ }^{74}$ When the firm expects practices to have much of their payoff in the future, and when there are numerous random factors affecting the level of the payoff, self-correcting tendencies will operate more slowly. Furthermore, with conglomerates, market discipline may have less effect on the practices of particular divisions. ${ }^{75}$

It would be a mistake to conclude from the limitations of the survivorship process that market evolution has little or no tendency to produce efficiency. What is required, and what much of the economic analysis responding to the shortcomings of simple price theory attempts, is a more subtle and intricate analysis of particular practices in particular contexts. Such examination would permit one to determine whether the market's corrective forces are sufficient to produce desirable consequences and, if not, whether there exist legal remedies that offer potential for improvement. This view is far less satisfying than the simple prescriptions of either the Chicago School ${ }^{76}$ or those who earlier took opposite positions, because it suggests that the most appropriate antitrust doctrine may have to be complex and it may not be possible to have great confidence in most conclusions reached concerning antitrust. In this state of affairs, even modest predilections about the outcome can produce substantial biases in the analysis, ${ }^{77}$ so extreme caution is necessary on the part of the analysts as well as the consumers of their product.

2. Formulation of Legal Rules. Much of the argument of the new law and economics of antitrust as well as many of the recent doctrinal developments, both in the Supreme Court and appellate courts, has been directed toward the formulation of legal rules and presumptions. For example, in areas such as vertical (intrabrand) restraints and tying, there has been advocacy and

74. Frank Easterbrook argues, as an explanation of why antitrust defendants should not be expected to justify their practices, that managers often will not know why they are doing what they do. See Easterbrook, supra note 62, at 5-6. But see Bork, supra note 50, at 12 ("The businessman knows which of these choices [enhancing efficiency or eliminating competition] he is making."). Aside from serious difficulties concerning the plausibility of this position, see Kaplow, Leverage, supra note 45 , at $543 \mathrm{n} .118$, the fact that even those adopting the practices are unaware of their purposes or effects would make it even less likely that the market's natural selection would operate quickly or effectively.

75. See also Scherer, supra note 45 , at $986-88$ (citing empirical evidence questioning the effectiveness of the takeover mechanism in eliminating inefficient performance).

76. The desire for simple, concrete, manageable prescriptions may explain much of the attraction to the Chicago School. See, e.g., Sullivan, Antitrust, Microeconomics, and Politics: Reflections on Some Recent Relationships, 68 CaLIF. L. REV. 1, 8-9 (1980); see also Kaplow, Leverage, supra note 45, at 555-56 \& n. 149; Kauper, The Burger Court and Antitrust Philosophy, 1981 Antitrust L. SYMP. 1, 12. For example, William Baxter, a strong advocate of courts using more sophisticated economic reasoning, insists on stopping short of having courts consider recent advances in economic analysis, for fear that "the lesson plan" for the courts will "become[] complicated so greatly." Baxter, supra note 30, at 320.

77. An important instance involves the bias that can result from the order in which analysis is conducted. See Kaplow, Leverage, supra note 45, at 552-55; see also Fox, The Politics of Law and Economics in Judicial Decision Making: Antitrust as a Window, 61 N.Y.U. L. REv. 554, 575-76 (1986) (attributing Frank Easterbrook's view to his selection of assumptions, a selection made on political, not economic or legal grounds). 
doctrinal movement from a per se prohibition to a rule of reason. ${ }^{78}$ Similarly, there has been increasing support for requiring proof of market power in an increasing range of contexts. ${ }^{79}$ In addition, the requirement that a plaintiff alleging predatory pricing prove that the defendant's prices were below cost, appropriately defined, has generally been well received by the courts in the past decade, although not without qualification. ${ }^{80}$ More generally, analysts advocating an economic approach have been hostile to considering evidence of a defendant's intent when evaluating conduct. ${ }^{81}$

In each case, the suggestion is that these results follow from economic analysis. This subsection demonstrates how none of these results is the necessary implication of an economic approach; in each instance, economic analysis could be used to support contrary positions. The discussion here will not, however, consider which positions on each question are most convincing; rather it will be confined to the issue of whether particular results inhere in economic logic.

The rule of reason might appear to have a natural affinity with economic analysis because the rule requires consideration of all the economically relevant factors, whereas the per se rule cuts analysis short. ${ }^{82}$ Yet the distinction between per se rules and the rule of reason is much like the more general distinction between rules and standards. With respect to that general distinction, it has been long recognized that the choice often has less to do with the goals of the particular system of rules than with the degree to which more rigid rules will produce error and more open-ended rules will produce uncertainty and impose additional cost in their application. It is precisely such trade-offs that economic analysis of legal procedure demands be made. ${ }^{83}$

78. Sylvania reversed Schwinn on the per se illegality of vertical territorial restraints, see supra at 187, although vertical price restraints are still per se illegal, see Continental T.V., Inc. v. GTE Sylvania, Inc., 433 U.S. 36, 51 n.18 (1977); Monsanto Co. v. Spray-Rite Serv. Corp., 465 U.S. 752, $761 \mathrm{n} .7$ (1984) (Court refusing to reconsider per se rule in that case), despite advocacy to the contrary, see, e.g., Posner, The Next Step in the Antitrust Treatment of Restricted Distribution: Per Se Legality, 48 U. Chi. L. Rev. 6, 8-14 (1981). Abolition of the per se rule for tying, which has long been advocated by the Chicago School, see, e.g., R. Bork, supra note 3, at 365-81; Bowman, supra note 14, received four votes in Jefferson Parish Hosp. Dist. No. 2 v. Hyde, 466 U.S. 2 (1984).

79. See, e.g., Jefferson Parish Hosp. Dist. No. 2 v. Hyde, 466 U.S. 2, $11-18$ (1984) (discussing nature of market power requirement in tying context); General Leaseways Inc. v. National Truck Leasing Ass'n, 744 F.2d 588, 596 (7th Cir. 1984) (Posner, J.); Jack Walters \& Sons Corp. v. Morton Bldg., Inc., 737 F.2d 698 (7th Cir.) (Posner, J.) (tying arrangement), cert. denied, 469 U.S. 1018 (1984); Valley Liquors, Inc. v. Renfield Importers, Ltd., 678 F.2d 742, 745 (7th Cir. 1982) (Posner, J.); Easterbrook, supra note 62, at 19-23. The Supreme Court has not, however, adopted a requirement of market power in all antitrust cases. See, e.g., NCAA v. Board of Regents of the Univ. of Okla., 468 U.S. 85, 109-10 (1984).

80. See, e.g., III P. Areeda \& D. Turner, supra note 58, ch. 7C; P. Areeda, Antrtrust Analysis 191 n.19 (3d ed. 1981) (citing commentary); Spivak, The Chicago School Approach to Single Firm Exercises of Monopoly Power: A Response, 52 AntrTRust L.J. 651, 654-63 (1983) (discussing cases).

81. See, e.g., General Leaseways, Inc. v. National Truck Leasing Ass'n, 744 F.2d 588, 595-96 (7th Cir. 1984) (Posner, J.); P. Areeda \& D. Turner, supra note 58, 1714.2 (Supp. 1987).

82. The classic statement of the rule of reason is in Chicago Bd. of Trade v. United States, 246 U.S. 231,238 (1918).

83. See, e.g., Ehrlich \& Posner, An Economic Analysis of Legal Rulemaking, 3 J. LEG. STUd. 257 (1974). Not all advocating the use of economics in antitrust insist on an inherent tension between per se rules and economics. See, e.g., Breyer, supra note 50 , at 8 . 
That a per se prohibition against horizontal price fixing is generally suported by those favoring an economic approach illustrates this point. ${ }^{84}$

Complicating the choice between a per se rule and the rule of reason is the ambiguity that surrounds their meaning, especially in the case of the latter. Richard Posner has remarked that the "content of the Rule of Reason is largely unknown; in practice, it is little more than a euphemism for nonliability." 85 If one takes this remark seriously, then all calls for the rule of reason (which are now heard in connection with every doctrine, except simple horizontal price fixing) should be understood as either intentionally or unconsciously disguised attempts to remove the area from antitrust scrutiny. Frank Easterbrook has similarly criticized the rule of reason as being largely devoid of content, ${ }^{86}$ and in its place advocates a series of five filters (presumptions) through which a plaintiff must pass in order to demonstrate liability. ${ }^{87}$ In principle the approach of trying to design such presumptions, where possible, is sound. Easterbrook's particular set, however, seems even more likely than the rule of reason to be tantamount to per se legality. ${ }^{88}$ Finally, it should be noted that the rule of reason, as currently formulated, does not permit the open-ended inquiry contemplated by statements equating it with a complete economic analysis in that it will not consider economic benefits of abandoning competition in particular instances. ${ }^{89}$

The preference for a market power proof requirement also appears to involve the application of an economic approach, because economic analysis indicates that, absent any such power, there can be no anticompetitive effect from restrictive practices. Yet, as with the rule of reason, it does not

84. See, e.g., Barry Wright Corp. v. ITT Grinnel Corp., 724 F.2d 227, 234 (1st Cir. 1983) (Breyer, J.); R. BoRk, supra note 3, at 279 (naked price fixing).

85. Posner, The Rule of Reason and the Economic Approach: Reflections on the Sylvania Decision, $45 \mathrm{U}$. ChI. L. Rev. 1, 14 (1977); see also Foer, The Political-Economic Nature of Antitrust, 27 ST. Louis U.L.J. $331,337-38$ (1983) ("With only slight exaggeration, there is really only one thing one needs to know about the rule of reason: when the rule of reason is applied, the defendant virtually always wins.").

86. See Easterbrook, supra note 62, at 9-14.

87. See id. at 14-39. One ambiguity in Easterbrook's framework concerns whether the plaintiff who has passed through all five filters is deemed to have prevailed or must then still prove liability under the rule of reason that Easterbrook has criticized.

88. See Kaplow, Leverage, supra note 45, at 529 n.57; see also id. at $544 \mathrm{n} .119$ (criticizing part of Easterbrook's foundation for his tendency to err in the direction of antitrust defendants). The discussion that follows of the market power threshold also refers to one of Easterbrook's filters.

89. This is the holding of National Soc'y of Professional Eng'rs v. United States, 435 U.S. 679 (1978); see also Catalano, Inc. v. Target Sales, Inc., 446 U.S. 643, 646-50 (1980). In their exuberance to see recent Supreme Court doctrine as a wholesale adoption of their economic approach, some Chicago School advocates have misunderstood this aspect of Engineers. For example, Peter Gerhart claims that only "a literal interpretation" of Engineers might be seen as embodying the false equation of competition and rivalry, see infra subsection IV-B-1, and the concomitant prohibition on considering the benefits deriving from ethical or safety norms. See Gerhart, supra note 2, at 331. Yet on the very next page he quotes the portion of Engineers that rules out consideration of precisely such a defense. See id. at 332. Later in the article, he returns to his original claim. See id. at 342. As another example, Thomas Kauper argues that this aspect of Engineers "can also be utilized to support the contention that the Burger Court's antitrust doctrine is solely efficiency oriented," a rather remarkable claim given his own characterization two sentences earlier that, under Engineers, "[w]hether competition is economically, socially or politically undesirable is simply not a relevant issue." Kauper, supra note 76, at 6-7 (emphasis added). 
immediately follow that economic analysis necessarily supports the rule that most directly reflects its application. Consider the context of horizontal price fixing. Frank Easterbrook has argued that the "market power inquiry logically precedes the question of whether a restraint is 'naked' and thus within the scope of the per se rule." 90 But such logic is formal at best. If a naked horizontal price-fixing scheme has been detected, and one is virtually certain that such schemes are undesirable, what sense does it make to require proof of market power when such an inquiry is inevitably difficult and costly?91 In addition, even if market power must be established, one must decide how much market power must be demonstrated, by what evidence, and with what degree of confidence. Such requirements further suggest the complexity of the link between an economic approach and particular antitrust rules. ${ }^{92}$

The emergence of a marginal cost pricing test for predatory pricing could also be seen as an outgrowth of the application of an economic analysis, although much of the criticism of the Areeda-Turner test has come from the most prominent economists who study antitrust. ${ }^{93}$ A substantial portion of the dispute concerns the appropriate role to be given complex dynamic considerations that are central to predatory phenomena. Some of the more recent court decisions on predatory pricing have veered from the AreedaTurner approach on precisely these grounds. ${ }^{94}$ Disputes concerning whether predatory investment and innovation should be treated similarly to predatory pricing often turn on similar factors. ${ }^{95}$ Arguments favoring the simpler Areeda-Turner approach have, not surprisingly, been quite similar to those

90. Easterbrook, supra note 62 , at 21.

91. See Kaplow, Leverage, supra note 45, at 547 n.127 (developing this criticism of Easterbrook and defending Phillip Areeda, whom Easterbrook castigates for suggesting that there should be some antitrust violations that do not require proof of market power, see Easterbrook, supra note 62 , at 29 n.62).

In addition, one could infer market power from the intent implicit in the practice, which raises the question of the role of inquiries into intent in an economic approach to antitrust, discussed later in this subsection.

92. The Supreme Court has recently and clearly reaffirmed its rejection of a market power requirement in cases involving naked restraints. See NCAA v. Board of Regents of the Univ. of Okla., 468 U.S. 85,109 (1984).

93. See, e.g., Baumol, Quasi-Permanence of Price Reductions: A Policy for Prevention of Predatory Pricing, 89 Yale L.J. 1 (1979); Josko \& Klevorick, A Framework for Analyzing Predatory Pricing Policy, 89 Y ALE L.J. 213 (1979); Scherer, Predatory Pricing and the Sherman Act: A Comment, 89 HARv. L. Rev. 869 (1976); Williamson, Predatory Pricing: A Strategic and Welfare Analysis, 87 YALE L.J. 284 (1977); see also Joskow, The Political Content of Antitrust: Comment, in ANTITrust Law and Economics 196, 202 (O. Williamson ed. 1980) (marginal cost pricing test has not prevailed "because of the triumph of economic efficiency considerations in the interpretation of antitrust statutes").

94. See Spivak, supra note 80, at 655-62 (citing, e.g., William Inglis \& Sons Baking Co. v. ITT Continental Baking Co., 668 F.2d 1014, 1035-36 (9th Cir. 1981) (prices above average variable cost may be predatory; ultimate test based on effectiveness in achieving predatory purposes), cert. denied, 459 U.S. 825 (1982)); Bordon, Inc. v. FTC, 674 F.2d 498, 514-16 (6th Cir. 1982) (price manipulation that achieves predatory purpose is a violation even if price is not below average variable cost), vacated per stipulation, 461 U.S. 940 (1983)).

95. See III P. AReedA \& D. Turner, supra note 58, Iף718-19, 721-22; Ordover \& Willig, $A n$ Economic Definition of Predation: Pricing and Product Innovation, 91 YALE L.J. 8 (1981). 
offered in support of per se rules rather than the rule of reason. ${ }^{96}$ Discussion of the marginal cost pricing test compliments that of the rule of reason in that, although both have been associated with the economic approach, they represent opposite choices in analytically similar situations. ${ }^{97}$ This juxtaposition does not indicate that either rule is mistaken; rather, it reinforces the argument that there is no automatic connection between the use of economic analysis and particular methods of formulating antitrust rules.

As a final example, consider the hostility often associated with the economic approach to antitrust and expressed with growing frequency toward inquiries into defendants' intent in order to resolve antitrust disputes. The basic problem is that the arguments rejecting altogether the relevance of intent are often based primarily on mistakes commonly made in particular inquiries into intent. More specifically, if intent is interpreted to encompass the simple desire to operate so effectively as to surpass one's competitors, it does not indicate any basis for antitrust liability. ${ }^{98}$ It hardly follows, however, that intent is irrelevant to an economic inquiry. ${ }^{99}$ For example, clear evidence that firms' intent in entering a complex joint venture arrangement was to use their integrated activities as a cover for price fixing is relevant in determining the likely effect of such an agreement. In determining the effects of allegedly predatory behavior, one might be aided by evidence that a firm reduced its prices to a lower level than was profit maximizing in the short run precisely because it anticipated that this would bankrupt a new entrant, keep away future entrants, and thus permit higher, monopolistic prices in the future.

It may reasonably be objected that such evidence will often be hard to come by, ${ }^{100}$ and may necessitate costly discovery if deemed admissible. Yet it

96. See III P. AREeda \& D. Turner, supra note 58, ch. 7C; Barry Wright Corp. v. ITT Grinnel Corp., 724 F.2d 227, 231-32, 234 (1st Cir. 1983) (Breyer, J.) (explicitly making the analogy to per se rules).

97. Another tension is that the marginal cost pricing test for predation assumes that the relevant costs can be measured with reasonable accuracy. In that event, however, the market power inquiries often thought necessary could employ similar information, without the need for market definition. See, e.g., Landes \& Posner, Market Power in Antitrust Cases, 94 Harv. L. Rev. 937, 940-41 (1981).

98. This conclusion follows regardless of the strength or manner in which intent is expressed. Intent to "crush, destroy, or mutilate" the competition is perfectly laudable if the method envisioned is the production of a better product.

99. The Supreme Court in Chicago Board's famous discussion of the rule of reason approach explicitly linked the utility of inquiries into intent to the understanding of the effects of behavior. Chicago Bd. of Trade v. United States, 246 U.S. 231, 238 (1918) ("the purpose or end . . . [is] relevant ... not because a good intention will save an otherwise objectionable regulation or the reverse; but because knowledge of intent may help the court to interpret facts and to predict consequences"); see also Brown Shoe Co. v. United States, 370 U.S. 294, 329 n.48 (1962); Broadcast Music, Inc. v. CBS, 441 U.S. 1, 19 (1979).

100. See, e.g., Areeda, in Are Economists Taking Over?, in Changing Antrtrust Standards 24, 26 (Conf. Bd. Research Bull. No. 144, 1983). One reason often given is that lawyers, aware of the relevance of such evidence, will advise that it be destroyed, or not created. Of course, there are some ethical questions raised by such behavior, and even if there were not any prohibitions currently, it would be possible to enact ethical or direct legal sanctions against such advice or practices by attorneys or others. As to evidence never created, there are surely limits on the ability of large corporations to make complex, long-range decisions, often involving the coordination of many subdivisions, without any written communications. This is a rather large issue that has received far 
is hardly obvious that direct proof of the effects of various complex business arrangements and practices-itself involving extensive discovery and heavy reliance on expert witnesses-will be easier to come by, less costly, or more reliable. ${ }^{101}$ Just as intent is often inferred from effects, ${ }^{102}$ it is also reasonable in many circumstances to infer effects from intent. After all, if one assumes, as many Chicago School analysts are inclined to do, that firms in the market are a better judge of the effects of practices than are courts, ${ }^{103}$ then it follows that such evidence of intent should be given great weight indeed. This evidence would necessarily be deemed superior to any attempt to reconstruct firms' decisionmaking processes using expert witnesses in the course of litigation. ${ }^{104}$

An economic approach does, however, have much relevance to an intent inquiry in that it will help determine which courses of action, if successful, are likely to be detrimental. Economic analysis and inquiries into intent are not inherently at odds. The question of how much weight one should place on various evidence of a firm's intent is a difficult one, and the only substantial insight economic theory is likely to offer is the general natural selection argument that firms more able to fulfill their intentions are more likely to survive than those that are not. ${ }^{105}$

\section{IV}

\section{Has There Been Significant Change in the Role of Economic Issues in Deciding Antitrust Cases? Economics as $A$ Goal Versus THE $O N L Y$ GoAL}

The first two parts of this article suggest that there has not been any significant increase in the degree to which the Supreme Court uses economic analysis in addressing economic questions, and that changes in the content of economic analysis over the past few decades have no necessary connection to most developments in antitrust doctrine and even less of a link to many of the positions advocated by the Chicago School of antitrust. This part examines a third possible explanation: that the politics and ideology of the Court and various antitrust analysts provide the best interpretation for much of the shift that has been noted.

One commonly offered observation is that economic efficiencyregardless of the particular content or method of economic analysis-has

\footnotetext{
too little attention; the limited claim here is that it is hardly obvious a priori that an economic approach should ignore this source of information.

101. See, e.g., L. Sullivan, supra note 59, at 110 (discussing predatory pricing).

102. Recall the common presumption that one intends the natural consequences of one's acts.

103. See supra subsection III-B-1.

104. Frank Easterbrook has argued that antitrust defendants are often unaware of the effects of their practices. See supra note 74; Easterbrook, supra note 62, at 5-6. In many of the relevant contexts, this claim is implausible. See Kaplow, Leverage, supra note 45, at $543 \mathrm{n} .118$. For example, firms do not create complex joint ventures by accident, and they do not make major pricing decisions by spinning roulette wheels. The claim in the text is not that firms' intent will always be clear to those on the inside or readily ascertainable from without, but rather that it offers a rather obvious potential source of information in many instances.

105. See supra subsection III-B-1.
} 
moved from being merely one of many dimensions of antitrust inquiry to the sole, or at least the heavily dominant, objective of antitrust in the mind of the Supreme Court. ${ }^{106}$ Of course, even if a radical transformation along these lines has taken place, the analysis presented in part III casts some doubt on whether such a shift necessarily explains the changes in the content of doctrine usually associated with the Chicago School. Nonetheless, such a departure from past practice is unlikely to be without effect and would itself reflect changes in the Court's approach that might have broader ramifications. As the introduction to this article suggested, in the light of changes in Supreme Court jurisprudence in many areas over the past decades, one should expect to see parallel movements in antitrust.

Section A considers how much change has occurred over the past decade in the Supreme Court's articulation of the purposes of the antitrust laws. The general conclusion is that the alleged movement is typically overstated.107 There are no clear affirmative statements embracing the philosophy that economic efficiency is all. At most, one observes a relative absence of strong statements concerning many competing objectives noted by the Court in the past. ${ }^{108}$

Section B interprets whatever change has occurred, as well as additional movement that might well emerge in the future. Also considered in that section are the political and institutional meanings of such a shift in objectives. Of course, whenever a substantial shift in ultimate objectives occurs, a strong political element is by definition present. Section B further argues that such a change as the one discussed in connection with antitrust,

106. See, e.g., Spivak, supra note 80, at 672 \& n.96 (discussing prominent Chicago School adherents). Spivak also notes that Judge Posner has essentially ruled to this effect in many of his recent antitrust opinions. See id. at $672 \mathrm{n.97}$; see also Changing Confugurations of Antitrust Law: Judge Posner's Application of His Economic Analysis to Antitrust Doctrine, 32 DE PAul L. Rev. 839, 881 (1983). These claims are somewhat difficult to interpret. Posner does repeatedly cite Reiter v. Sonotone Corp., 442 U.S. 330,343 (1979), to support the view that "consumer welfare"-by which the Chicago School often means "efficiency to the exclusion of all other objectives" - has been endorsed as the purpose of antitrust. This argument and interpretation concerning Reiter $v$. Sonotone are discussed in subsection IV-A-2.

This article will not explore the additional fallacy common in the efficiency-only approach: that the concept of efficiency necessarily rules out direct consideration of "alternative" objectives. For example, as Herbert Hovenkamp has noted, conventional free-rider arguments, which the Chicago School emphasizes in explaining vertical restraints, could justify, on economic grounds, concerns for political power and opportunity for small businesses. See Hovenkamp, supra note 12, at 243.

107. Richard Markovits, a supporter of the Burger Court's changes, initially puts the argument somewhat more realistically than most. "In short, although the tea leaves are admittedly scanty, the Burger Court appears to be preparing an antitrust brew with an exclusively efficiency flavor." Markovits, supra note 6, at 183 . Yet, aside from this qualification, he proceeds as though there is very little doubt. See, e.g., id. at 184 ("As we have seen, the mature Burger Court rejected the Warren Court's noneconomic values."), 196 ("Burger Court has distinguished itself . . . by insisting that the antitrust laws contain an exclusively economic test of legality" (emphasis added)).

108. Even this later aspect is difficult to interpret, as the time period and number of cases is sufficiently limited to leave some doubt as to the significance of any trend. After all, it has never been claimed to be the case that dozens of opinions each decade in the past contained substantial elaborations of the purposes of antitrust, including explicit emphasis on noneconomic objectives. And numerous references to competing objectives still appear with moderate frequency in Supreme Court opinions. For some examples, see subsection IV-A-2. 
when read against the background of the legislative and social history as well as prior interpretations of the antitrust laws, contains an important activist element, as that term is understood in the current legal and political climate. ${ }^{109}$ To the extent one takes seriously the claims of the current national administration, recent judicial appointees, and their sympathizers, this characterization of the changes supports the frequent allegation that avowed opposition to judicial activism more often reflects opportunism rather than any sincere, principled belief. 110

\section{A. Assessing the Change in Antitrust Opinions}

1. The Early Cases. Although some have taken the view that, from the beginning, the sole objective of the antitrust laws was to be economic efficiency, ${ }^{11}$ there has never been any dispute over the fact that leading antitrust opinions from the beginning have made explicit references to broader purposes, such as the protection of small business, entrepreneurial freedom, buyer freedom of choice, the maintenance of deconcentration both as a way of life and to avert undue influence on the political process, and the preservation or promotion of a fair distribution of income, particularly between large economic enterprises and consumers. One of the first wellknown instances is Justice Peckham's reference in Trans-Missouri to "small dealers and worthy men whose lives had been spent" in business. ${ }^{112}$ In Alcoa, Learned Hand stated that " $[\mathrm{t}]$ hroughout the history of these statutes it has been constantly assumed that one of their purposes was to perpetuate and preserve, for its own sake and in spite of possible cost, an organization of industry in small units which can effectively compete with each other." 113

Interestingly, both statements refer explicitly to the Sherman Act, which has been the focus of the strongest claims to the effect that the antitrust laws contemplated only economic efficiency, rather than the Clayton Act (including the 1950 amendment to section 7) or the Robinson-Patman Act, where efficiency-only proponents have been more willing to concede alternative motivations. Moreover, these statements precede the Warren Court era, thus indicating a long-standing pattern rather than a temporary shift during that

109. This article will not explore the important question of whether these conventional interpretations are meaningful from various perspectives. Rather, it makes the rather modest claim that alleged and advocated antitrust developments concerning the law's fundamental objectives fall within the concept of activism as it is generally understood.

110. Many would question whether "principled" opposition to activism is conceptually coherent. See supra note 109.

111. See infra subsection IV-B-1.

112. United States v. Trans-Missouri Freight Ass'n, 166 U.S. 290, 323-24 (1897). Interestingly, although Klor's, Inc. v. Broadway-Hale Stores, Inc., 359 U.S. 207 (1959), an early Warren Court decision, is perhaps most strongly associated with this view of antitrust laws, it contains no reference to this statement in Trans-Missouri or similar statements, and devotes only passing attention to the objectives of the antitrust laws, concluding its brief discussion by referring to the potential for monopoly, as traditionally understood. See id. at 213-14.

113. United States v. Aluminum Co. of Am., 148 F.2d 416, 429 (2d Cir. 1945). For a discussion of how this view might be reconciled with the statement in United States v. United States Steel Corp., 251 U.S. 417, 451 (1920), that size per se is not an offense, see Kaplow, Market Power, supra note 45, at $1824 \&$ n.20. 
time. When one moves to the Warren Court, and beyond the Sherman Act context, similar statements can be found. The review of the legislative history of the 1950 amendment to section 7 of the Clayton Act in Brown Shoe includes the following statement:

The dominant theme pervading congressional consideration of the 1950 amendments was a fear of what was considered to be a rising tide of economic concentration in the American economy. ... O Other considerations cited in support of the bill were the desirability of retaining "local control" over industry and the protection of small businesses. Throughout the recorded discussion may be found examples of Congress' fear not only of accelerated concentration of economic power on economic grounds, but also the threat to other values a trend toward concentration was thought to pose. ${ }^{114}$

Perhaps more important was the Court's later comment that, although

[i]t is competition, not competitors, which the Act protects[,] . . we cannot fail to recognize Congress' desire to promote competition through the protection of viable, small, locally owned businesses. Congress appreciated that occasional higher costs and prices might result from the maintenance of fragmented industries and markets. It resolved these competing considerations in favor of decentralization. ${ }^{115}$

Antitrust court decisions up through the time of the Warren Court thus clearly reflect the view that objectives other than economic efficiency, narrowly construed, are part of the purposes of antitrust legislation.

2. Supreme Court Decisions of the Past Decade. In light of the history briefly recounted in subsection 1 , it would indeed represent an important shift if the Burger Court's recent decisions explicitly rejected earlier statements and adopted the view that economic efficiency was the sole objective of the antitrust laws. Most of the support for this frequently advanced description is confined to a handful of passages in some of the Court's recent opinions. As an initial observation, given that none of the referenced language spans more than a sentence or two and none represents a direct attempt to address this issue, it is impossible to make a persuasive claim beyond the argument that such language constitutes hints of things to come. One rather obvious source of support for this characterization of the evidence of a shift as modest at best is the simple fact that the Court neither cites nor otherwise addresses any of the well-known discussions of the multiple objectives position it has supposedly rejected in recent cases.

It is best to begin the inquiry with the most widely cited Supreme Court statement on the subject, that found in Reiter $v$. Sonotone: "On the contrary, [the floor debates] suggest that Congress designed the Sherman Act as a 'consumer welfare prescription.' R. Bork, The Antitrust Paradox 66 (1978)."116 Believe it or not, that single sentence and citation has been the major source of much of the argument. Not only is the evidence exceedingly thin in quantity, it also falls far short of supporting the position that the goal of economic efficiency, to the exclusion of all else, was therein adopted.

114. Brown Shoe Co. v. United States, 370 U.S. 294, 315-16 (1962).

115. Id. at 344.

116. Reiter v. Sonotone Corp., 442 U.S. 330, 343 (1979). 
First, the phrase "consumer welfare prescription" admits substantial ambiguity. Although Robert Bork and others may have economic efficiency in mind, it would hardly be surprising if the Court intended a meaning more literal and in accord with common usage-the welfare of consumers. That interpretation, of course, often conflicts with economic efficiency. It excludes, for example, economies that accrue to a firm but are not passed on to consumers. In fact, this straightforward reading is more in accord with the distributional interpretation of the Sherman Act's objectives. ${ }^{117}$ One would be hard-pressed to support either position based on this brief passage. ${ }^{118}$

A second major defect is that even if the statement in Reiter $v$. Sonotone is interpreted as expressing the antitrust laws' concern with economic efficiency, it does not on its face purport to exclude other objectives. Thus, the statement is irrelevant to the question at hand because those who advocate a multiple-goal interpretation and approach generally embrace efficiency as one of the important goals. In fact, the context of the quotation clearly suggests that the statement of the consumer welfare goal is being used in an inclusive, rather than exclusive, fashion. The issue in Reiter $v$. Sonotone, after all, was whether consumers who purchase products for their own use have standing under section 4 of the Clayton Act. ${ }^{119}$ The context thus stands the exclusive interpretation on its head, for it was conceded by all parties and apparently agreed by the Court that various other potential plaintiffs-businesses in particular-did have standing. Thus, to interpret the Court's remark as referring only to consumers would be odd indeed. ${ }^{120}$ The only question was whether consumers were to be included among those allowed to bring private suits. It is hardly surprising that the Court provided a unanimous affirmative response. ${ }^{121}$ The paragraph containing the "consumer welfare" reference exists to support the proposition that "[n]othing in the legislative history of $\S 4$ conflicts with" the holding that injured consumers could bring private suits. ${ }^{122}$ The sentence preceding the reference to the floor debates refers to the respondent's assertion that the language of section 4 "was clearly intended to exclude pecuniary injuries" to consumers. ${ }^{123}$

117. See, e.g., Lande, Wealth Transfers as the Original and Primary Concern of Antitrust: The Efficiency Interpretation Challenged, 34 HAstings L.J. 65 (1982).

118. The fact that the citation is to Judge Bork, who takes the efficiency view, is insufficient to resolve the controversy. In addition to the arguments in text, it is clear that such a brief quotation with no indication of context is inevitably difficult to interpret. Moreover, since there are numerous clear statements of the efficiency view in Bork's book that were not quoted, it seems all the more difficult to claim that this brief reference was meant to signal adoption of the efficiency view.

119. See 442 U.S. at 334.

120. In fact, the Chicago School position is that, in many contexts (when the affected businesses are competitors of rather than purchasers from defendants), only consumers should be permitted to sue. See, e.g., Easterbrook, supra note 62, at 33-39. The Court's approach, taken as a whole, seems more difficult to reconcile with that position than with one that considers goals beyond economic efficiency.

121. But see 442 U.S. at 345-46 (Rehnquist, J. concurring) (worrying about the resulting increase in litigation that will be produced, but seeing it as a question for Congress).

122. 422 U.S. at 342.

123. Id. at 343 (emphasis added). 
The only remaining argument that could be offered to support the claim concerning the historic significance of Reiter $v$. Sonotone is that the mere fact of the reference to the first part of Bork's book reflects a wholesale adoption of a new philosophy of antitrust. Gordon Spivak's assessment of this argument provided a cogent reply: "Imagine that: the Supreme Court overruled decades of antitrust precedents simply by quoting three words from Judge Bork's book." 124

Nor do the rest of the Supreme Court's recent pronouncements amount to a wholesale revolution on this front. One of the strongest statements in support of the Chicago School position is that found in BMI, indicating that the Court's per se inquiry is to determine "whether the practice facially appears to be one that would always or almost always tend to restrict competition and decrease output, ... or instead one designed to increase economic efficiency and render markets more, rather than less competitive." "125 Yet statements to this effect are hardly new, as evidenced by the Court's citation of Northern Pacific in support of this proposition. ${ }^{126}$ In addition, as the discussion in part III indicates, the focus on competition in Engineers is not at all necessarily an endorsement of the efficiency approach, as either an exclusive objective or otherwise. ${ }^{127}$ Surely additional passages could be cited, but, given the extremely limited support offered by the language most frequently employed in discussions of whether the efficiency objective has fully triumphed, one cannot reasonably expect that even lesser clues would substantially tip the balance. ${ }^{128}$

124. Spivak, supra note 80, at 673; see also Comment, supra note 106, at 881 n.213.

125. Broadcast Music, Inc. v. CBS, 441 U.S. 1, 19-20 (1979) (quoting United States v. United States Gypsum Co., 438 U.S. 422, 441 n.16 (1978)).

126. Northern Pac. Ry. v. United States, 356 U.S. 1, 4 (1958). Northern Pacific is a Warren Court decision, and one of the many that has come under attack from the Chicago School. See, e.g., R. Bork, supra note 3 , at 367.

127. See supra at 196 \& note 89 . Thus, only minimal support for the efficiency-only approach can be gleaned from Engineers' references to competition and economics. See, e.g., 435 U.S. at 690-91 \& nn. $16 \& 17$. It is also relevant that the entire discussion of these issues in Engineers appears in a context wherein the Court was rejecting a defense that did not appeal to the frequently proffered non-efficiency objectives of antitrust and would be ruled out quite readily by an ordinary interpretation of the word "competition." (For further exploration of the meanings of "competition," see subsection IV-B-1.)

An example of the significance of this is Frank Easterbrook's thesis that " $[t]$ he task of antitrust policy is to find the right balance of competition and cooperation." Easterbrook, supra note 44, at 1707; see Easterbrook, supra note 62, at 1-2. Since the rule of reason explicitly states otherwise-i.e., only "competition" is deemed relevant-this is deeply problematic for his argument that the Supreme Court's approach largely coincides with his.

128. Some further support for the claim that the Supreme Court has moved in the direction of considering only efficiency can be found in a footnote in Sylvania, wherein the Court rejects a lower court judge's appeal to "the autonomy of independent businessmen even though [the restrictions] have no impact on 'price, quality, and quantity of goods and services.'" 433 U.S. at 53 n.21. Instead, the Court indicates that antitrust policy must be linked in some manner to "marketplace considerations [to provide some] objective benchmarks." Id. Yet it specifically quotes Schwinn, 388 U.S. at 374 , in rejecting the alternative interpretation, 333 U.S. at $53 \mathrm{n} .21$, suggesting that the Court's statement in Sylvania can hardly be seen as a wholesale change from the Warren Court on this question. To illustrate, the Warren Court's analysis in Brown Shoe, which is often noted for 
Not only is the affirmative support weak, but some modest language cuts against the notion that efficiency now reigns alone. Maricopa ${ }^{129}$ is probably the decision most embarrassing to the Chicago School position in that it failed to accept a more lenient approach toward maximum price fixing, as advocated by Frank Easterbrook. ${ }^{130}$ The Court placed "horizontal agreements to fix maximum prices on the same legal-even if not economic-footing as agreements to fix minimum or uniform prices."131 Both Maricopa and Associated General Contractors quoted language from Kiefer-Stewart concerning the tendency of condemned practices to "cripple the freedom of traders and thereby restrain their ability to sell in accordance with their own judgment." 132 The existence of these opinions and the statements within them cast further doubt on the claim that the Supreme Court has fully reversed itself on the question of the goals of the antitrust laws. ${ }^{133}$

Concerning both the objectives of antitrust, discussed in this part, and the content of economic analysis, considered in part III, there is the danger of drawing stronger inferences than warranted from the fact that a larger portion of major antitrust decisions by the Burger Court had been in favor of antitrust defendants, in cases where the Chicago School would support such results, than was true of prior Courts. As a matter of logic, much of the optimistic reading by Chicago School proponents ${ }^{134}$ might be attributed to the following invalid syllogism: (1) The Court has produced a given set of results; (2) this set of results has been advocated by proponents of the new law and economics of antitrust (the Chicago School); (3) therefore, the Supreme Court has been convinced by and therefore has adopted the Chicago School's economic interpretation of and approach to antitrust law. ${ }^{135}$ The hidden premise necessary to make this argument valid is that it is impossible to reach the Court's results without adopting the Chicago School position, lock, stock,

suggesting nonefficiency objectives of antitrust, did quite explicitly ground its decision in its analysis of effects in the marketplace. The same is true with Alcoa.

Frank Easterbrook argues that many of the numerous decisions following his approach are unanimous. See Easterbrook, supra note 44, at $1705 \& \mathrm{n} .23$. It is unclear why it does not seem to him important that almost half of the cases he lists reject his positions in whole or in part. (Most of the directly relevant language in the other half of the cases has already been discussed.)

129. Arizona v. Maricopa Co. Med. Soc'y, 457 U.S. 332 (1982).

130. See Easterbrook, Maximum Price Fixing, 48 U. CHI. L. REv. 886 (1981).

131. 457 U.S. at 348 (emphasis added).

132. Kiefer-Stewart Co. v. Joseph E. Seagram \& Sons, Inc., 340 U.S. 211,213 (1951), cited in Arizona v. Maricopa Co. Med. Soc'y, 457 U.S. 332, 346 (1982), and Associated Gen'l Contractors v. California State Council of Carpenters, 459 U.S. 519, 528-29 \& n.18 (1983). Associated General Contractors also indicated that adverse effects on "free choices between market alternatives is inherently destructive of competitive conditions and may be condemned even without proof of its actual market effect." Id. at 528 (citing Klor's, Inc. v. Broadway-Hale Stores, Inc., 459 U.S. 207, 210 $14(1959))$.

133. As another example, although the Court's recent decision in NCAA emphasized effects on price and output, 468 U.S. at 107, it also explicitly referred to competitors' ability to compete at two points, id. at $107,108$.

134. The same can be said of similar readings by pessimistic opponents of the Chicago School.

135. The logic behind arguments that the Chicago School has triumphed is rarely this explicit; perhaps coming closest is the statement in Kauper, supra note 76 , at 5, although he finds pronouncement of a Chicago School triumph somewhat premature, id. at 2, 6, 12. See also Markovits, supra note 6. 
and barrel. In rebutting this argument, one obvious point is simply that many of the more recent statements and decisions have been approved by a wide array of commentators, including those hostile to the Chicago School. More generally, recalling the argument in the introduction to this article concerning general movements in Supreme Court decisionmaking as well as the role of particular rationalizations for decisions, ${ }^{\mathbf{1 3 6}}$ it would be a difficult task indeed to establish that positions of any particular group of commentators have been adopted by the Court.

\section{B. Political Meaning of the Change: Judicial Activism}

To the extent one accepted the argument of section A sufficiently to conclude that there has been no significant change in the Court's position concerning the goals of the antitrust laws and further assumed that no further substantial change in such a direction was imminent, the question would be whether continuation of the past approach was warranted. Similarly, if one believes that substantial change has already occurred or is on the horizonfor example, if it is going to be implemented, or at least attempted, in the federal appellate courts-one would similarly have to assess the basis for past and potential future approaches concerning the purposes of antitrust. Subsection 1 explores the basis in the statutes and their legislative history for various positions on this issue. It generally concludes that the interpretations of the early courts were consistent with these foundations, suggesting that a fundamental departure would constitute an activist move. Subsection 2 briefly explores the dissonance between the fundamental positive tenet of Chicago law and economics as a whole (beyond the antitrust context), that the common law develops in a manner that is inevitably efficient, and the central battle cry of the Chicago School's position in antitrust, that antitrust doctrine-which has been formed by an essentially common law process-has quite frequently been inefficient. To the extent this inconsistency exists, it reinforces the interpretation offered in this article concerning the primacy of the political and ideological dimension to proposed and allegedly observed shifts in antitrust law along the lines advocated by the Chicago School.

1. The Antitrust Statutes and Their History. The very existence of continued debate over whether the antitrust statutes and their legislative history contemplate economic efficiency as the sole objective of antitrust doctrine is striking. The position of some Chicago School advocates in this area represents an instance in which their arguments are so farfetched that it is hard to take them seriously; yet the continued advocacy of this position by some $^{137}$ makes at least a limited discussion necessary. Moreover, even for

136. On the latter, see supra note 7.

137. See, e.g., R. BoRk, supra note 3, ch. 2; Bork, Legislative Intent and the Policy of the Sherman Act, $9 \mathrm{~J}$. L. \& ECon. 7 (1966). One of the most extreme statements is by Robert Bork:

There would be little point in reviewing here all of the positions that have been advanced concerning the broad social, political, and ethical mandates entrusted to the courts through the Sherman Act, or in naming the persons who have urged them, for there is not a scintilla of 
those advocates who make little use of the statutes and their legislative history, the fact that they cut strongly against the view of efficiency as the sole objective of the antitrust laws is relevant for interpreting the advocates' implicit views concerning the role of the judiciary.

The claim that the antitrust laws contemplate economic efficiency as their sole objective has a number of deficiencies, many of which are independently sufficient to rule out the possibility. First, those enacting the lawsparticularly in the case of the Sherman Act-could not have understood the concept as we are now asked to believe they did. Second, if one accepts the Chicago School's analysis of restrictive practices, the language of many of the enactments is virtually impossible to reconcile with the idea of efficiency being the sole objective. Third, the legislative history and political context of all the enactments render the efficiency-only interpretation implausible.

Regardless of any ambiguity in the statute itself or in its legislative history, it is virtually impossible that the Sherman Act could have been crafted with only economic efficiency in mind. At this time in history, legislators gave little attention to what economists had to say on such issues. ${ }^{138}$ If economists had been consulted, the legislature would have known that the profession at that time was generally hostile to the very idea of antitrust law. ${ }^{139}$ Perhaps most decisive, economists of the day did not yet understand economic efficiency in its current form. In particular, the most straightforward efficiency argument against cartels and monopoly - the one the Chicago School has in mindrefers not to efficiency in production but rather to allocative efficiency, which designates the welfare loss due to the misallocation of resources resulting from purchase decisions that are based upon super-competitive prices. Yet, at the time of the Sherman Act's passage, this aspect of efficiency was making only its first appearance in economics literature, and it was not until decades

support for most such views anywhere in the legislative history. The only value other than consumer welfare which is even suggested by the record is protection of small businessmen, but, as will be argued, that value was given only a complementary and not a conflicting role. The legislative history, in fact, contains no colorable support for application by courts of any value premise or policy other than the maximization of consumer welfare. The legislators did not, of course, speak of consumer welfare with the precision of a modern economist but their meaning was unmistakable.

Id. at 10 (emphasis added) (in interpreting this quotation, one should keep in mind that "consumer welfare" is meant to be synonymous with efficiency, as will be discussed further below).

The positions offered by Richard Posner and Frank Easterbrook on this score are more modest. See R. Posner \& F. Easterbrook, supra note 3, at 152-54. Phillip Areeda and Donald Turner advocate that efficiency be the sole objective of antitrust, see I P. AREEDA \& D. Turner, supra note 58, ch. IB, although they make their case largely on grounds of practicality, making only brief note of the legislative history for the purposes of indicating that it is largely unilluminating, see id. $\$ 106$.

138. See, e.g., R. Hofstadter, The Paranoid Style in American Politics and Other Essays 200 (1965).

139. See, e.g., id. at 200-02; W. Letwin, Law and Economic Policy in America $71-77$ (1965); Blake, Conglomerate Mergers and the Antitrust Laws, 73 Colum. L. REv. 555, 577 (1973); Rowe, supra note 16, at $1516 \mathrm{n} .24$; Rowe, in Are Economists Taking Over?, supra note 100, at 24 ("Antitrust revisionists today would resurrect Senator Sherman as a bearded Milton Friedman. But the Darwinian economists of 1890 would not touch antitrust with a ten-foot pole."); Stigler, The Economists and the Problem of Monopoly, 72 AM. Econ. Rev. 1, 3 (1982) (one "would have searched long and hard" in 1890 to find "any economist who had ever recommended" such a policy). 
later that economists generally came to understand and apply the concept. ${ }^{140}$ It is thus inconceivable that members of Congress were motivated at all by such an argument-much less solely motivated by it. ${ }^{141}$ This is not to suggest that efficiency was irrelevant. To the extent industrial combinations might be the most efficient means of production, efficiency considerations constituted an argument against antitrust law, or at least against excessive application. Although such concerns can be found in the legislative debates, they can hardly be read as constituting the sole basis favoring enactment of the legislation. ${ }^{142}$

The statutory language of antitrust legislation itself poses additional problems for the Chicago School positions. If one accepts the arguments advanced by some-that cartelization largely subsumes antitrust concerns from an efficiency perspective ${ }^{143}$ - then the rest of the antitrust laws, including section 2 of the Sherman Act, which are seen as conflicting with efficiency, must necessarily be explained by resort to other objectives. ${ }^{144}$ In addition, practices such as tying and exclusive dealing are alleged generally to be efficient, although they are specifically targeted by section 3 of the Clayton Act. Mergers are considered unproblematic unless they raise cartelization (or perhaps monopolization) concerns already covered by the Sherman Act, requiring that section 7 of the Clayton Act, which was subsequently enacted and amended precisely to strengthen the Sherman Act prohibitions, be read as a redundancy that can safely be ignored. Finally, the Robinson-Patman Act, which is generally viewed as most clearly contrary to efficiency, is to be disregarded, perhaps by interpreting it (like the Clayton Act) in such a manner that no action would constitute a violation. ${ }^{145}$ Although all of the

140. The Sherman Act was passed at the beginning of 1890 . Mike Scherer has noted that Marshall's first edition, which initially brought this concept of deadweight loss to Anglo-American economics, did not appear until 1890, with the only earlier references being an "obscure Englishlanguage precursor" originally published in 1871 and a variant that was published in French in 1844. See Scherer, supra note 45, at $977 \&$ n.20; see also Lande, supra note 117 , at 88 n.97.

141. Robert Bork and others make much of references in the debates to higher prices and lower output, which are the twin effects of monopoly that result in a loss of allocative efficiency. See, e.g., R. Bork, supra note 3, at 61-62; Bork, supra note 137, at 14-21. To note those effects, however, is a far cry from being motivated by notions of efficiency. These arguments are consistent with general concerns for consumers or small business purchasers, including concerns for the distribution of income. See, e.g., Lande, supra note 117, at 83-96 (suggesting that income distribution was in fact the original and primary concern); Scherer, supra note 45, at 979 ("Congress was concerned at least as much with income distribution effects (which were well-understood in 1890) as with efficiency effects (which were not)."). Thus, the reference to price and quantity can be explained most persuasively in a manner suggesting that efficiency was not even one of Congress' concerns. Regardless, the references to many other purposes, discussed in the remainder of this subsection, make it clear that efficiency was not the sole objective.

142. See, e.g., Lande, supra note 117 , at $89-93$

143. See, e.g., R. Bork, supra note 3, at 405-06 (also including mergers to monopoly and some predation); R. Posner, supra note 3, at 212-17.

144. One argument sometimes advanced is that efficiency was the sole motivation for most or all of the enactments, but that it was misunderstood. As a result, one should follow the objectives and ignore, or read in a manner to render moot, all the conflicting statutory language, no matter how explicit. An example involving the interpretation of "competition" in the Clayton Act is discussed below.

145. See, e.g., Bork, supra note 50, at 9. But see Breyer, supra note 50, at 9 (disagreeing with Bork). 
proscriptions in the antitrust statutes are at least somewhat ambiguous-and section 1 of the Sherman Act is the height of ambiguity, unless it is read sufficiently literally as to prohibit virtually all contracting - they are not wholly without content. Moreover, the content they contain is often inconsistent with economic efficiency if one accepts the Chicago School's views concerning what is efficient. ${ }^{146}$

One particular question of interpretation of the statutory language-the meaning of "competition" in many of the antitrust provisions-arises in numerous contexts and has been the focus of substantial attention. The Chicago School position is that competition should be taken to mean economic efficiency, rather than some notion of business rivalry that would include the preservation of large numbers of competitors or entrepreneurial freedom as part of the objective. ${ }^{147} \mathrm{~A}$ commonly advanced corollary to this position is that competitors should not be permitted to bring antitrust suits. ${ }^{148}$ This interpretation, of course, is directly opposed to the sort offered in Brown Shoe, discussed previously. 149

Robert Bork, who perhaps devotes the most attention to the issue, has recognized that "competition" has meanings in regular usage other than the one he advocates. ${ }^{150}$ He claims, however, that various reasons justify his interpretation and that his reading "[s]urely . . . is consistent with everyday speech."15I Yet because most who speak on the subject do not even understand what Bork and other Chicago School adherents mean by

146. Viewing the statutes alone-ignoring the earlier argument concerning when allocative efficiency first came to be understood, problems with interpreting "competition," and the legislative history-one might be able to resurrect an efficiency-only position if one thought many practices that are the target of the antitrust laws were in fact inefficient. See also supra note 144.

147. See, e.g., Roland Mach. Co. v. Dresser Indus., Inc., 749 F.2d 380, 395 (7th Cir. 1984) (Posner, J.); University Life Ins. Co. of Am. v. Unimarc Ltd., 699 F.2d 846, 853 (7th Cir. 1983) (Posner, J.) (in referring to the argument that rivalry is not an objective: "That 'there's a special providence in the fall of a sparrow, Hamlet, Act V, sc. II, line 232, is not the contemporary philosophy of antitrust."); Products Liab. Ins. Agency, Inc. v. Crum \& Foster Ins. Cos., 682 F.2d 660, 663-64 (7th Cir. 1982) (Posner, J.); R. Bork, supra note 3, 51, 58-61, 91 (the "whole task of antitrust . . [is] to improve . . efficiency"); Gerhart, supra note 2, at 321,330-31; Fox, supra note 1, at 37 (discussing statements of former FTC Chairman Miller). Frank Easterbrook implicitly takes this position in Easterbrook, Is There a Ratchet in Antitrust Law?, 60 TEx. L. REv. 705, 714-15 (1982). Although this argument is usually reserved for the Clayton Act and the Robinson-Patman Act, he also asserts that "the Sherman Act is written in the language of 'competition,' and economic terms," id. at 714 , which is rather surprising since the word does not appear anywhere in that enactment.

As a simple example, this interpretation would presumably permit a merger of all firms in an industry-thus eliminating all competition-so long as there were sufficient economies of scale, despite $\S 7$ 's flat prohibition on mergers that "may . . substantially . . lessen competition, or ... tend to create a monopoly."

148. This position is advanced in Easterbrook, supra note 62, at 33-39, and expressed in many of Richard Posner's antitrust opinions. See, e.g., Brunswick Corp. v. Riegel Textile Corp., 752 F.2d 261, 266-67 (7th Cir. 1984), cert. denied, 472 U.S. 1018 (1985); cases cited supra note 147.

149. See supra at 202.

150. See R. BORK, supra note 3 , at $58 \mathrm{n}$.*.

151. Id. at 61 . Quite striking is his statement that since the models implicit in the Clayton Act "are derived from economics rather than sociology or political science, this usage would seem to rule out all but economic goals." Id. at 58 . Similar pseudo-deduction would, for example, rule out all public health objectives in statutes promoting competition in the health sector and would rule economic considerations out of much defense procurement and many other areas. 
efficiency, the notion that theirs is one of the common uses of "competition" is problematic. Although hardly decisive, standard dictionary definitions of "competition" offer as a synonym "rivalry," the Chicago School's excluded meaning, and all the definitions offered refer to the rivalry concept, none admitting the Chicago School's meaning. ${ }^{152}$ Not only does the Chicago School economic interpretation directly contradict common usage, ${ }^{153}$ it also is inconsistent with the usage of the term by economists, who do mean rivalry rather than economic efficiency when they refer to "competition." The standard definitions of perfect competition and monopolistic competition, both of which stress rivalry, ${ }^{154}$ make this fact apparent. Moreover, economists have no reason to define "competition" as "efficiency" because they have explicitly adopted separate terms for the two concepts. Economic theorists go about proving that competition produces efficiency in some circumstances and inefficiency in others; the language by which they describe their efforts clearly reveals that they use "competition" to describe the process of interaction (existence of rivalry, specified in various ways) and "efficiency" to characterize the properties of the result of many processes, of which competition is only one. ${ }^{155}$ It is clear that "competition" means economic efficiency in the minds of a few antitrust advocates and no one else. ${ }^{156}$

The efficiency-only interpretation also is clearly contrary to the legislative history of all the antitrust statutes. A few highlights from the rather familiar story should suffice. The legislative history of the Sherman Act-which is the only antitrust enactment Chicago School advocates even attempt to address seriously ${ }^{157}$-reveals countless references to nonefficiency objectives. These

152. See, e.g., Webster's New Collegiate Dictionary 230 (1977).

153. By directly contradict, I mean that, as between the two definitions under consideration, the one the Chicago School castigates is precisely the one implied by common usage and the one they advocate has no connection whatsoever to common usage.

154. See, e.g., E. Mansfield, Microeconomics 234-35, 302 (2d ed. 1975).

155. See, e.g., T. Koopmans, Three Essays on the State of Economic Science $1-126$ (1957); H. Varian, Microeconomic Analysis 136-57 (1978). One can also compare the definitions of "competitive markets," "monopolistic competition," and "perfect competition"-all defined in terms of large numbers of entities, each of limited significance-and those of "allocative efficiency" and "pareto optimum" - defined in terms of economic performance-in D. Pearce, The Dictionary of Modern Economics 14, 74-75, 292-93, 325, 329 (1981). See also The McGraw-Hill Dictionary of Economics 90-91 (D. Greenwald, et al., 3d ed. 1983) (defining "competition" in terms of rivalry).

156. Robert Bork goes so far as to argue that to the extent Congress meant something other than "what we usually think of as competition"-i.e., if Congress meant rivalry and not efficiency-it constitutes "a fraud upon the electorate." Bork, supra note 50, at 9 (emphasis added).

Another problem is that the Chicago School interpretation of "competition," when combined with their view that many practices cited in those sections of the antitrust laws referring to injury to competition are never anticompetitive in the sense of impairing efficiency, essentially reads much of the antitrust prohibitions out of existence. See supra at 208-09; Fox, supra note 77 , at $572-73$. Although this is defended as the only way to make sense of the provisions, such a conflict would not arise if "competition" were read in a manner more in accord with common usage and the legislative history of the provisions.

157. A striking example is in a recent paper by Frank Easterbrook, who, in response to Herbert Hovenkamp's discussion of legislative history (which explicitly makes this point, see, e.g., Hovenkamp, supra note 12, at 249-50), only addresses the Sherman Act. See Easterbrook, supra note 44, at 170205. In addition, one of his main arguments is that the efficiency-only approach differs little from a broader one, see id. at 1703, which makes one wonder what to make of the large portion of Chicago 
references are consistent with all theories concerning the political climate surrounding the law's enactment. ${ }^{158}$ The Robinson-Patman Act, implemented during the New Deal, was explicitly directed toward protecting small business. ${ }^{159}$ The very nature of the strong economic criticism that this Act has received attests to the fact that its objectives are not solely (if at all) the promotion of economic efficiency. ${ }^{160}$ Another clear example, the 1950 amendment to section 7 of the Clayton Act, ${ }^{161}$ was expressly directed at social and political aspects of economic concentration, as well as the protection of small business, rather than at enhancing economic efficiency. ${ }^{162}$ Thus, even relatively more recent congressional action, taken after modern concepts of efficiency had become widely known, at least among economists, unmistakably

School argument that explicitly criticizes prior decisions and commentary for admitting other objectives into the analysis and thereby producing bad results.

Much of Easterbrook's defense of the efficiency-only approach makes no attempt to ground itself in the statute or legislative history. For example, he insists that a multiple objective approach is not "sane", id. at 1703-04-a position hardly consistent with the teachings of economics. Compare $\mathbf{R}$. Bork, supra note 3, at 79-80 (rejecting the propriety of a multiple objective approach), with Easterbrook, supra note 44, at 135 (criticizing the focus on one economic consideration when others are also implicated). Moreover, he selects as the single goal the only one that could not have been intended by Congress.

158. See, e.g., R. HofSTADTER, supra note 138, at 199-200 ("Among the three [goals], the economic [one] was the most cluttered with uncertainties, so much so that it seems to be no exaggeration to regard antitrust as being essentially a political rather than an economic enterprise." (footnote omitted)), 205-11; H. Thorelli, The Federal Antrtrust Policy, ch. 4 (1955); Fox, The Modemization of Antitrust: A New Equilibrium, 66 CoRnell L. REv. 1140, 1147-48 (1981); Lande, supra note 117, at 82-106; Rowe, supra note 16, at 1513-17; Stigler, The Origin of the Sherman Act, 14 J. Leg. STud. 1 (1985) (suggesting protection of small business as a primary motivation). Richard Hofstadter traces some of the changes in views concerning antitrust, business, and the economy since that time, see $R$. HofsTADTER, supra note 138 , at 212-28, although the most recent major substantive antitrust legislation, the 1950 amendment to Clayton Act $\$ 7$, evidences that similar motivations to those at the time of the Sherman Act were clearly central.

159. See, e.g., Jefferson County Pharm. Ass'n, Inc. v. Abbott Laboratories, 460 U.S. 150, 170-71 (1983); R. HofSTADTER, supra note 138, at 221; Hansen, Robinson-Patman Law: A Review and Analysis, 51 Fordham L. Rev. 1113 (1983); Rowe, supra note 16, at 1519 (quoting Rep. Patman advocating a "policy of live and let live," "protect[ing] the weak against the strong and prevent[ing] men from injuring one another," 80 CoNG. Rec. 3447 (1936)).

160. See, e.g., R. Bork, supra note 3, at 382-401 ("antitrust's least glorious hour"); F.M. SCHERER, supra note 67 , at 580-82 (questioning whether beneficiaries include any except attorneys involved in litigation concerning application of the provision).

161. The original Clayton Act and the Federal Trade Commission Act, both passed in 1914, reflected objectives similar to those involved in enactment of the Sherman Act—objectives other than economic efficiency. See, e.g., Lande, supra note 117, at 106-30.

162. See, e.g., Brown Shoe, 370 U.S. at 311-23; Bok, Section 7 of the Clayton Act and the Merging of Law and Economics, 74 Harv. L. Rev. 226, 233-38 (1960); Cann, Section 7 of the Clayton Act and the Pursuit of Economic "Objectivity": Is There Any Role for Social and Political Values in Merger Policy?, 60 Notre Dame L. REv. 273, 277-84 (1985); Fox, supra note 158, at 1149-51; Lande, supra note 117, at 130-42; Rowe, supra note 16, at 1523-24. Derek Bok's statement provides a good summary of the legislative history as it relates to the issue of objectives:

To anyone used to the preoccupation of professors and administrators with the economic consequences of monopoly power, the curious aspect of the debates is the paucity of remarks having to do with the effects of concentration on prices, innovation, distribution, and efficiency. To be sure, there were allusions to the need for preserving competition. But competition appeared to possess a strong socio-political connotation which centered on the virtues of the small entrepreneur to an extent seldom duplicated in economic literature.

Bok, supra, at 236-37. 
reflects motivations other than, and sometimes in opposition to, economic efficiency. ${ }^{163}$

Thus, it is not merely eight decades of "aberrant" court opinions but also a clear indication in both the statutes and their legislative history that supports the proposition that economic efficiency does not constitute the sole objective of the antitrust laws. ${ }^{164}$ It thus is hardly surprising that some who hold views close to those of the Chicago School have called for the repeal or substantial modification of significant portions of the antitrust statutes. ${ }^{165}$ The entire history is sufficiently uncertain and vague that no particular pattern of antitrust doctrine can be defended against all others as a simple matter of fidelity to Congress. Furthermore, notions of economic efficiency surely constitute an important component of any sensible interpretation of the antitrust statutes. For the courts to proclaim efficiency as the sole objective of antitrust, however, would constitute a substantial political act indeed, and precisely the sort that would be condemned by those who generally counsel judicial restraint and defend the judicial role as being distinct from that of the legislature.

2. Efficiency of the Common Law versus Inefficiency of Antitrust Law. Until now, most of the discussion of the new law and economics of antitrust has been presented without consideration of the more recent and wider movement in law and economics, ${ }^{166}$ significant elements of which are particularly associated with a "Chicago School." Juxtaposing developments in both areas is illuminating, especially since the central tenets of the two Chicago Schools are in conflict. This conflict arises from the major proposition of the Chicago School of law and economics that the common law is efficient ${ }^{167}$-in contrast

163. Interestingly, economists and other scholars interested in and informed about the antitrust laws have interpreted the legislation in political and social terms rather than as focused primarily, much less exclusively, on economic efficiency. See R. HofstadTer, supra note 138, at 233.

Frederick Rowe develops the argument that economic concentration, broadly construed, rather than economists' concepts of market power and efficiency, were historially at the core of the antitrust enactments, and the economic approach did not emerge until it was employed as part of an aggressive litigation strategy in the 1940's aimed at making it easier, rather than more difficult, to find antitrust liability. See Rowe, supra note 16, at 1521-22, 1524, 1529-32, 1560-61.

164. Interestingly, Richard Posner cites the Sherman Act as one of the statutes he would characterize, like some constitutional provisions, as used by courts more as pretexts for their decisions, wherein the language is never explicitly referenced and the case law is used as both the beginning and end of the inquiry. See $\mathbf{R}$. Posner, supra note 60 , at 278 . He similarly suggests that the common law nature of the antitrust statutes, see infra subsection IV-B-2, may free the judge from having to consult the legislators' values at all. See, R. Posner, supra note 60, at 288. Of course, as demonstrated in section $A$ of this part, Posner would have to free himself of the case law, as well as the statutes and their legislative history, in order to leave sufficient room for him to advance the efficiency-only approach toward antitrust.

165. See, e.g., R. Posner, supra note 3, at 7, 212-17. Recent Reagan Administration proposals and statements by particular officials could also be noted.

166. The use of economics in antitrust has been explicitly distinguished from the new law and economics more generally. See supra at 184 .

167. See, e.g., R. Posner, supra note 3; Posner, Some Uses and Abuses of Economics in Law, 46 U. CHI. L. REv. 281, 287-97 (1979). "[T] hese problems [with the economic theory of the common law] do not include the alleged inadequacy of "efficiency" ... as a normative criterion. The positive theory 
to claims that it should be efficient or that economic analysis is useful in predicting the effects of common law rules. ${ }^{168}$

Antitrust law may not appear to fit within this framework, but the conflict appears once one recognizes that antitrust has long been viewed in many respects as a common law subject-in light of its common law origins in the law of restraint of trade and its development for nearly a century by courts faced with the task of interpreting many rather open-ended enactments. ${ }^{169}$ In fact, Congress apparently contemplated a common law type of development when it enacted the Sherman Act. ${ }^{170}$ In his recent book on federal courts, Richard Posner notes the tension that results from this recognition:

But at another level the inclusion of antitrust [as a "quasi" common law field] may seem simply to demonstrate the fatuity of my enterprise of associating federal common law with economic efficiency. For is it not the teaching of an extensive literature-to which I, among many others, have contributed-that the courts, in interpreting the antitrust statutes, have misused economic principles to produce a body of doctrine fairly riddled with economic fallacies? ${ }^{171}$

In fairness, Posner explicitly limits himself to a brief discussion of this question, ${ }^{172}$ but given the potential importance of this fundamental contradiction in two extensively developed lines of work, his attempted resolution is worth considering.

The primary argument he offers for distinguishing antitrust is that, during the Warren Court, ${ }^{173}$ the government brought a large portion of the cases and was permitted direct appeal to the Supreme Court, with the result that

says only that the common law appears to be an engine of wealth maximization, not that it should be one." Id. at 291 (emphasis in original).

168. More recently, Richard Posner's writings have devoted considerable attention to the proposition that efficiency (wealth maximization) should be the objective of the common law. See, e.g., Posner, The Ethical and Political Basis of the Efficiency Norm in Common Law Adjudication, 8 Hofstra L. Rev. 487 (1980); Posner, Utilitarianism, Economics, and Legal Theory, 8 J. LEc. STUd. 103 (1979). This claim has been subject to extensive debate. See, e.g., Symposium on Efficiency as a Legal Concern, 8 Hofstra L. Rev. 485 (1980); Dworkin, Is Wealth a Value?, 9 J. Leg. Stud. 191 (1980); Kronman, Wealth Maximization as a Normative Principle, $9 \mathrm{~J}$. LEg. STUD. 227 (1980). There is no doubt, however, that Posner continues to maintain his descriptive claim independently.

Many law and economics scholars not associated with the Chicago School have devoted most of their attention neither to whether the common law is efficient nor to whether it should be, but rather to predicting the effects of common law rules and determining which are efficient and which are not. See, e.g., A. Polinsky, An Introduction to Law and Economics (1983); Shavell, Strict Liability versus Negligence, 9 J. Leg. STud. 1 (1980).

169. See, e.g., National Soc'y of Professional Eng'rs v. United States, 435 U.S. 679,688 (1978); II P. Areeda \& D. Turner, supra note 58, ch. 3A; R. Posner, supra note 60, at 288, 301; Baxter, Separation of Powers, Prosecutorial Discretion, and the "Common Law" Nature of Antitrust Law, 60 TEx. L. REv. 661, 662-73 (1982); Easterbrook, supra note 147, at 706 \& n.5; Easterbrook, Legal Interpretation and the Power of the Judiciary, 7 Harv. J.L. \& PuB. Pol. 87, 93 (1984).

170. See, e.g., United States v. Associated Press, 52 F. Supp. 362, 370 (S.D.N.Y. 1943) (Hand, J.) ("Congress has incorporated into the Anti-Trust Acts the changing standards of the common law"), aff'd, 326 U.S. 1 (1945); II P. AREeda \& D. Turner, supra note 58, 1302.

171. R. POSNER, supra note 60 , at 301 .

172. See id.

173. Posner's focus on the Warren Court might suggest that the rejection of the efficiency approach was an aberration of that era, contrary to the clear indications in section IV-A. For example, Learned Hand's prounouncements in Alcoa, see supra at 201, as well as his discussion of monopolization, preceded and were accepted by the Supreme Court well before that time period. Other cases frequently criticized were in the 1930's and 1910's. 
only a handful of judges were determining antitrust doctrine. ${ }^{174}$ Posner claims that a "[p]olicy so determined is unlikely to be very stable."175 The question, however, is why such an approach would interfere with the general efficiency properties of the common law. All federal common law is largely determined ultimately by the Supreme Court. Although in other areas there may have been appellate court opinions to lend assistance, it is difficult to see how the lack of an intermediate opinion would fundamentally alter either the quality and consistency of Supreme Court opinions or the basic objectives that were pursued. The persuasiveness of a distinction on this ground is even more dubious in light of the fact that many of the district court opinions are famous for their care (and length), and a number were crafted by the most respected federal judges of their time. In addition, despite the fact that antitrust law may shift over generations more rapidly than does the common law, ${ }^{176}$ section IV-A demonstrated that one result has been largely constant for nearly a century: The courts have been guided by objectives other than efficiency. Moreover, in the past decade, where direct appeal to the Supreme Court was no longer available, the alleged movement toward efficiency that Posner applauds is attributed to Supreme Court decisions, and not traced in any way to lower courts. ${ }^{177}$ Thus, to the extent there has been a substantial move in the efficiency direction, it seems rather difficult to attribute it to this procedural change rather than, for example, to more general currents in the Supreme Court over the past fifteen years.

There exists, of course, another rather direct way to resolve this contradiction. One could argue that antitrust is not really a common law

174. See R. Posner, supra note 60 , at 302.

175. Id. In claiming that the Court has since played a smaller role, having "relatively infrequent occasions when it decides antitrust cases these days," id. at 302-03, one would infer that the number of antitrust opinions rendered each year by the Supreme Court had substantially decreased, but examination of statistics appearing in the Harvard Law Review that summarize the Supreme Court's docket each Term over the past few decades and direct computer searches reveal that the decline, if any, is insubstantial. (The mean may have fallen from approximately five full opinions per Term to slightly over four, and the variance is less.) A recent compilation shows that the large decrease in government-initiated cases is significantly offset by the increase in private antitrust cases, and that there was little decline from the early Burger Court (over half the cases arising when the expediting act was in effect) to the later Burger Court. See Hellman, Case Selection in the Burger Court: A Preliminary Inquiry, 60 Notre Dame L. Rev. 947, 1051-52 (1985). Moreover, it is not clear why it would be that having a smaller group of cases in a given time period facilitates development of the common law either in a more orderly fashion or in an efficiency direction.

176. Given recent developments in products liability law, landlord-tenant law, and other areas, this assumption is hardly obvious. It is offered in the text merely for the sake of argument.

177. Some of the more important of these decisions applauded by the Chicago School involved reversals of the lower courts. See, e.g., Jefferson Parish Hosp. Dist. No. 2 v. Hyde, 66 U.S. 2 (1984); Reiter v. Sonotone Corp., 442 U.S. 330 (1979); Broadcast Music, Inc. v. CBS, 441 U.S. 1 (1979); United States Steel Corp. v. Fortner Enters., Inc., 429 U.S. 610 (1977). In addition, Sylvania was applauded for overruling Schwinn, but this was not the basis for the decision in the appellate court, Continental T.V., Inc. v. GTE Sylvania Inc., 433 U.S. 36 (1977). General Dynamics, which is often regarded as heralding the new era, was a direct appeal under the expediting act, United States $v$. General Dynamics Corp., 415 U.S. 486 (1974). Of course, with the recent judicial appointments of appellate court judges associated with an economic approach, and in particular that of the Chicago School, the Supreme Court can expect in the future to have ever more guidance from appellate courts to educate them in an efficiency direction. 
subject after all because the statutes, as explained in subsection IV-B-1, simply give too much of a directive to take an approach other than one focused exclusively on economic efficiency. As to the antitrust enactments after the Sherman Act, Posner does offer this point as a partial explanation. ${ }^{178}$ Once this out is taken, however, the argument comes full circle: If the resolution of the apparent contradiction requires the claim that the antitrust laws preclude the efficiency approach, then the activism that would be involved in interpreting them as advocated by the Chicago School of antitrust becomes all the more clear. ${ }^{179}$

\section{$\mathrm{V}$}

\section{Conclusion}

Important changes in antitrust law have occurred over the past fifteen years. The thesis of this article is that this shift has been misunderstood-not as to the content of the newly evolved doctrine, but rather as to the explanation for the change. The Introduction suggested that these developments are more plausibly understood in the context of broader, and in many respects parallel, shifts in all the Supreme Court's decisions. The preceding discussion supports this conclusion. As part II demonstrated, it simply is not the case that economic analysis is used substantially more frequently in examining economic issues. Part III indicated that, although economic analysis has changed substantially in the past five decades, the Chicago School of antitrust and many of the doctrinal shifts by the Supreme Court are hardly necessary outcomes of such a change. Finally, part IV indicated how changes in the purported objectives of antitrust in the direction of considering only economic efficiency have been overstated. Moreover, to the extent these changes have occurred or will occur in the future, they are best understood as an activist recreation of antitrust rather than as any attempt to return to the statutes or their original meaning. ${ }^{180}$

Overall, recent changes in antitrust-actual or advocated-are in large respect a function of politics, even though the position advocated is defined in

178. See R. POSNer, supra note 60 , at 302.

179. Another tension between these two areas arises from Posner's advocacy of the efficiency of common law characterization based primarily on his interpretation of observed evidence (court decisions), even in the absence of a compelling theoretical basis for this alignment. See, e.g., Samuels \& Mercuro, Posnerian Law and Economics on the Bench, 4 INT'L Rev. L. Econ. 107, 108 (1984). Yet it is precisely such an approach by those using case studies to explore industrial organization that Posner has criticized. See supra at 189.

180. In an early survey of the Burger Court's antitrust jurisprudence, Posner explicitly advanced the position that the Court's primary difference from the Warren Court was its less activist, more restrained approach. See Posner, The Antitrust Decisions of the Burger Court, 47 ANTrTrust L.J. 819, 821 25 (1978). The primary reasons offered for this conclusion were the narrow grounds for decision offered (noting the exception of Sylvania, and not describing instances of Warren Court activism) and greater "deference to district court fact findings in the defendant's favor." Id. at 822 . If the Burger Court has in fact made little change in antitrust doctrine, it could hardly be characterized as activist. But the changes attributed to it by many are contrary to such a reading, in which case section IV-B's analysis indicates the appropriateness of an activist characterization. 
terms of economics. In this respect, antitrust resembles constitutional law. ${ }^{181}$ Of course, when shifts in Supreme Court doctrine arise, one should not be surprised to observe the Court referring to academic literature supporting the results in order to lend further credibility to its opinions, ${ }^{182}$ just as the Warren Court used economics and cited relevant literature in support of its opinions. ${ }^{183}$

One direct ramification of characterizing the Chicago School approach as activist is that the appointment of Chicago School advocates to the bench would appear inconsistent with the stated policy of the national administration against judicial activism and in opposition to any appointments who might not share this view. ${ }^{184}$ It is not only that Chicago School adherents advocate the reversal of long-standing precedents, such as Dr. Miles' prohibition of resale price maintenance, ${ }^{185}$ but that its position is substantially at odds with congressional enactments over almost a century. Of course, this contradiction between opposition to activism and the desire to reshape the antitrust laws would be unimportant if, as is frequently suggested, rhetoric concerning judicial activism and fidelity to Congress is reserved for areas in which one favors or opposes particular results. If one is to take any cues from antitrust, the best explanation for the appointment of federal judges associated with the law and economics of the Chicago School is not a desire to improve the economic sophistication of the federal judiciary but rather an attempt to further the effort to have the composition of the judiciary reflect particular political views. ${ }^{186}$ Thus, the title of this conference-Economists on the Bench-and of this session-Impact of Economically Sophisticated Judges on Economically Sensitive Areas of the Law-convey a misleading impression of what these recent events have been about.

181. It is relevant that in both areas, as well as in most others, Burger Court changes generally do not reflect changes in the opinions of the same Justices over time, but rather the fact that recent appointees decide cases differently than those replaced. Major doctrinal changes in antitrust history have similarly reflected changing personnel. See, e.g., Standard Oil Co. v. United States, 221 U.S. 1 (1911) (both Justices remaining from earlier, anti-rule-of-reason cases retained same position).

182. See supra note 7. Eleanor Fox has noted how the Chicago School economic approach may be a politically congenial source of support given contemporary mixes of political forces. See Fox, supra note 77 , at 588 .

183. See supra part Iİ.

184. Not surprisingly, recent Chicago School appointees, like most, claim to be opposed to judicial activism. See, e.g., Bork, Emerging Substantive Standards-Developments and Need for Change, 50 ANTITRUST L.J. 179, 180 (1982) (criticizing alleged activism of Warren Court antitrust decisions); Easterbrook, supra note 169.

185. Dr. Miles Medical Co. v. John D. Park \& Sons. Co., 220 U.S. 373 (1911). The effect of a potential reversal is heightened by Congress' recent repeal of the 1930's statute that overrode the prohibition under certain circumstances. See, e.g., Continental T.V., Inc. v. GTE Sylvania Inc., 433 U.S. 36, 51 n. 18 (1977).

186. The Administration's 1987 nominations of Supreme Court Justices bear this out. Eleanor Fox's conclusion concerning former FTC Chairman Miller provides a useful contrast. See Fox, supra note 1 , at 54-55. 